\title{
The Above-Anvil Cirrus Plume: An Important Severe Weather Indicator in Visible and Infrared Satellite Imagery
}

\author{
KRISTOPHER BEDKA \\ Science Directorate, NASA Langley Research Center, Hampton, Virginia \\ Elisa M. Murillo AND CAMERON R. HOMEYeR \\ School of Meteorology, University of Oklahoma, Norman, Oklahoma \\ BENJAMIN SCARINO \\ Science Systems and Applications, Inc., Hampton, Virginia \\ HAIDEN MERSIOVSKY \\ Department of Meteorology, Florida State University, Tallahassee, Florida
}

(Manuscript received 15 March 2018, in final form 16 July 2018)

\begin{abstract}
Intense tropopause-penetrating updrafts and gravity wave breaking generate cirrus plumes that reside above the primary anvil. These "above anvil cirrus plumes" (AACPs) exhibit unique temperature and reflectance patterns in satellite imagery, best recognized within 1-min "super rapid scan" observations. AACPs are often evident during severe weather outbreaks and, due to their importance, have been studied for 35+ years. Despite this research, there is uncertainty regarding why some storms produce AACPs but other nearby storms do not, exactly how severe are storms with AACPs, and how AACP identification can assist with severe weather warning. These uncertainties are addressed through analysis of severe weather reports, NOAA/National Weather Service (NWS) severe weather warnings, metrics of updraft cloud height, intensity, and rotation derived from Doppler radars, as well as ground-based total lightning observations for 4583 storms observed by GOES super rapid scanning, 405 of which produced an AACP. Datasets are accumulated throughout storm lifetimes through radar object tracking. It is found that 1) AACP storms generated 14 times the number of reports per storm compared to non-AACP storms; 2) AACPs appeared, on average, $31 \mathrm{~min}$ in advance of severe weather; 3) 73\% of significant severe weather reports were produced by AACP storms; 4) AACP recognition can provide comparable warning lead time to that provided by a forecaster; and 5) the presence of an AACP can increase forecaster confidence that large hail will occur. Given that AACPs occur throughout the world, and most of the world is not observed by Doppler radar, AACP-based severe storm identification and warning would be extremely helpful for protecting lives and property.
\end{abstract}

\section{Introduction and background}

\section{a. Severe weather indicators from visible and infrared imagery}

Geostationary satellites (GEOsats) provide a wealth of multispectral observations of severe convective storms throughout the world. The research and operational forecasting communities seek new approaches to detect and

\footnotetext{
Corresponding author: Kristopher Bedka, kristopher.m.bedka@ nasa.gov
}

predict severe storms from space to extend forecast lead times and protect lives and property, especially over regions without weather radar coverage. Over the past several decades, unique patterns within convective cloud tops and cloud evolution depicted by GEOsat imagery have been deemed useful by the operational forecasting or research communities for severe storm detection and/or short-term $(0-2 \mathrm{~h})$ forecasting. These include but are not limited to

1) rapid cloud-top cooling during storm initiation (Cintineo et al. 2013), 
2) overshooting cloud tops (Dworak et al. 2012; Bedka and Khlopenkov 2016, and references therein),

3) the presence of anomalously small water droplets or ice crystals within an ensemble of developing cumulus and within anvils (Lindsey et al. 2006; Rosenfeld et al. 2008),

4) enhanced wind flow divergence and vorticity within anvil cloud top (Apke et al. 2016, 2018),

5) above-anvil cirrus plumes, cold rings, and enhancedV signatures (Setvák et al. 2010; Bedka et al. 2015; Homeyer et al. 2017), and

6) anomalous storm motion relative to other nearby storms (e.g., "a right mover") indicating a strong likelihood of a rotating updraft and supercell storm (Lindsey and Bunkers 2005).

Severe storms often evolve rapidly, developing from fair-weather cumulus to cumulonimbus clouds spanning the depth of the troposphere and producing damaging wind, hail, or tornadoes in as little as $1 \mathrm{~h}$ (e.g., Koch et al. 2016). However, in many regions of the world, GEOsat imagers observe at 15-min intervals. This sampling frequency when coupled with the additional time required to access the imagery, compute derived products, and display and analyze the imagery/products can be inadequate for exploiting the above signatures to improve severe weather forecasting. Higher temporal resolution imagery can help one to better observe these processes, enhancing the utility of satellite data in the forecast process.

\section{b. GOES Super Rapid Scan observations}

Beginning in the summer of 2012, the GOES-14 satellite operated in Super Rapid Scan Operations for GOES-R (SRSOR) mode. It collected imagery at 1-min intervals to help the community prepare for the increased temporal resolution of the GOES-R series Advanced Baseline Imager (ABI) imagery (from $30 \mathrm{~s}$ to $1 \mathrm{~min}$; Schmit et al. 2005, 2014). Prior to the first GOES-14 SRSOR, 1-min imagery was only collected for a few days during preoperational satellite checkout periods or for limited time periods during high-impact weather events such as tropical cyclones. The GOES-14 SRSOR periods typically persisted for several weeks and provided sustained observations of diverse natural phenomena including wildfires, snowstorms, tropical cyclones, and severe convection.

The benefits of super rapid scan imagery were quickly recognized by the forecasting and research communities. GOES-14 SRSOR imagery helped National Oceanic and Atmospheric Administration (NOAA)/Storm Prediction Center forecasters better recognize newly developing convection and issue severe weather watches, and better identify areas of persistent overshooting cloud top (OT) activity where severe weather is concentrated (Line et al. 2016). SRSOR imagery was used to identify rapid cloudtop temperature and updraft intensity changes within OTs that preceded reports of damaging winds, hail, and tornadoes (Schmit et al. 2014; Bedka et al. 2015). The imagery also enabled the development of cloud-top divergence and vorticity products derived from mesoscale atmospheric motion vectors that indicate updraft acceleration and rotation preceding large hail and tornadoes (Apke et al. 2016, 2018), which were not possible to derive with previous-generation 15-30-min GOES-8-15 data. In March 2017, preliminary GOES-16 ABI imagery became available in order to introduce forecasters to this new data prior to GOES-16 becoming operational in late December 2017. The 30-s to 1-min imagery of convection has been routinely collected by GOES-16, providing new opportunities for improved diagnoses and predictions of severe storms.

\section{c. Above-anvil cirrus plumes: Identification and storm severity}

Super rapid scan imagery enables early identification of the above-anvil cirrus plume (AACP) signature. Intense tropopause-penetrating updrafts, commonly referred to as OTs, in storm-relative wind environments favoring gravity wave breaking leads to cirrus plumes that can reside several kilometers above the primary anvil (Wang 2003; Setvák et al. 2013; Homeyer et al. 2017). The lofting of cloud material during a wave breaking event is consistent with the early physical descriptions of cloud-top evolution during plume formation by Fujita (1982), where it was given the name "jumping cirrus." The height differential and differing ice microphysics between the AACP and primary anvil combine to generate unique texture that allow AACPs to be readily identified in visible wavelength imagery. AACPs often cast shadows on the primary anvil near sunset, which provides an additional indication of their occurrence in visible imagery. A GOES-16 visible image of two storms over Argentina in Fig. 1a shows this AACP texture. The northern storm produced hail over $18 \mathrm{~cm}(\sim 7$ in.) in diameter in Córdoba, Argentina, near the time of this image (Cappucci 2018). The severity of the southern storm is unknown.

In many situations, the AACP adjusts to the ambient temperature of the lower stratosphere, causing the AACP infrared (IR) brightness temperature (BT) to be warmer than the underlying anvil, most notably in areas adjacent to the OT updraft region. The warm AACP BT contrasts sharply with the cold OT that is continuously reinforced by rapidly rising air that cools upon ascent due to adiabatic expansion. The AACP warm anomaly 


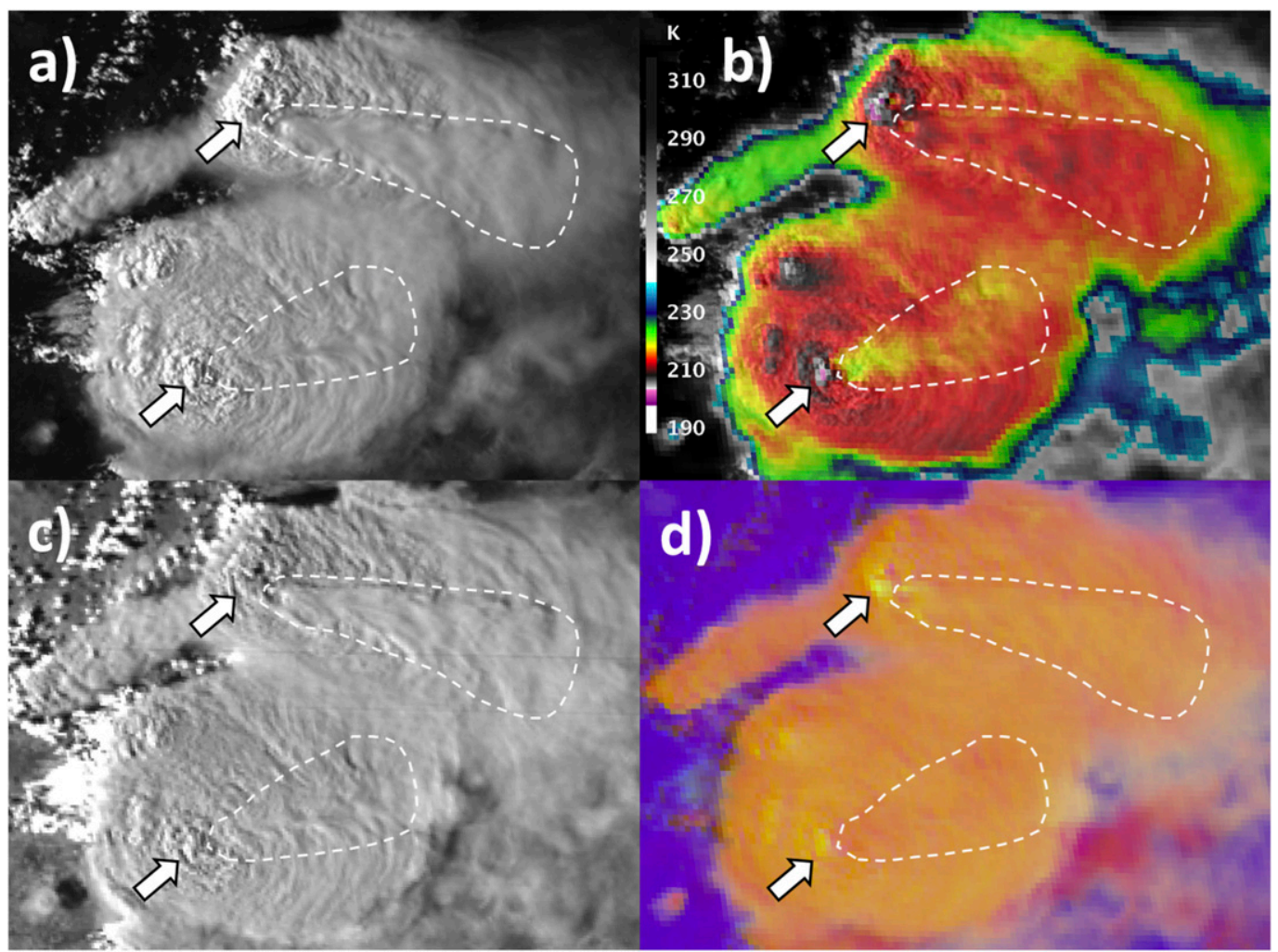

FIG. 1. (a) GOES-16 0.64- $\mu \mathrm{m}$ visible, (b) $10.3-\mu \mathrm{m}$ IR+visible sandwich composite, (c) $1.61-\mu \mathrm{m}$ near-IR, and (d) daytime convection RGB composite imagery of convective storms over Argentina at 2030 UTC 8 Feb 2018. The sandwich composite method allows for display of both IR and visible imagery in one graphic through the use of the semitransparency of the IR channel. (Setvák et al. 2013). Locations of two AACPs are outlined by dashed lines, and overshooting cloud tops responsible for triggering the AACP are identified by white arrows. The northern AACP storm generated hailstones exceeding $18 \mathrm{~cm}$ (7 in.) in diameter in Córdoba, Argentina, near the time of these images.

is often embedded within a U-, V-, or ring-shaped area of colder temperature emanating from the primary anvil. These features have been referred to in previous studies as the enhanced- (or cold) U, V, or ring signatures (Adler et al. 1983; McCann 1983; Brunner et al. 2007; Setvák et al. 2010; Homeyer 2014; Bedka et al. 2015; Homeyer et al. 2017). AACP IR BT patterns can be more complex than these signatures and further observational and modeling studies are required to fully understand why a storm appears as it does at a particular time. For example, the AACP from the Córdoba storm in Fig. 1b is colder than its primary anvil, whereas the southern storm in this image has an AACP that is warmer than the anvil, resulting in an enhanced-V signature. These complexities will be discussed in detail in section 3a.

Many studies have noted the presence of AACPs, enhanced Vs, or cold-ring signatures in the vicinity of severe weather using operationally available GEOsat or low-Earth-orbiting imagery (McCann 1983; Brunner et al. 2007; Púčik et al. 2013; Kunz et al. 2018). Using GOES-3 imagery collected at 30-min intervals, McCann
(1983) found that an enhanced-V signature appeared $30 \mathrm{~min}$ on average in advance of severe weather. GOES-14 Super Rapid Scan imagery enables more precise determination of AACP timing relative to observed severe weather. Manual identification of 58 AACP-producing cells occurring during the 2012 GOES-14 SRSOR period showed that $57 \%$ of the AACP cells were severe (Bedka et al. 2015). AACPs appeared, on average, 18 min before the storm's first severe weather report, with many AACPs offering greater than 30-min lead time. Severe weather incidents can go unreported, especially over sparsely populated regions (Doswell et al. 2005; Verbout et al. 2006; Brotzge et al. 2011). Thus, it is likely that AACPproducing storms are more often severe than these statistics suggest.

Significant severe weather outbreaks can feature dozens of AACP-producing storms, and AACPs have been found within convection across the globe (Setvák et al. 2013). McCann (1983) found that storms with enhanced V's were associated with $50 \%$ of $\mathrm{F} 2$ or greater intensity tornadoes analyzed in his study (76 of 152 storms). 
Figure 2 shows a random sample of eight significant severe storms that generated $\mathrm{EF} 4+$ tornadoes, hail of $18+\mathrm{cm}(7+\mathrm{in}$.$) , or 44.7+\mathrm{m} \mathrm{s}^{-1}\left(100+\mathrm{mih}^{-1}\right)$ measured wind gusts. An AACP was evident within all eight storms, including those observed by GOES-7 that collected IR data at $\sim 10 \mathrm{~km}$ per pixel resolution over the central United States, comparable to the imagery analyzed by McCann (1983). Arrows indicate where the plume texture and warm anomalies were most evident in visible and/or IR imagery, which are not always directly adjacent to the severe storm updraft core. Storms with OTs and no AACP often generate hazards such as lightning, heavy rainfall, aviation turbulence, and aircraft engine icing conditions (Bedka et al. 2010; Yost et al. 2018). However, OTs are a ubiquitous feature atop deep convection throughout the world but severe weather is quite infrequent relative to the total number of OTproducing storms. Only a small subset of OTs, those that penetrate the tropopause $>1 \mathrm{~km}$ within storm-relative wind environments favorable for gravity wave breaking, were found to generate AACPs (Homeyer et al. 2017).

Research published to date, coupled with the examples shown in Figs. 1 and 2, indicates the AACP signature is one of the strongest indicators of a severe storm depicted by visible and IR satellite imagery. Despite the extensive research devoted to the AACP and related enhanced-V and cold-ring signatures, there is lingering uncertainty regarding 1 ) the processes that trigger and sustain an AACP, 2) how these processes are depicted by conventional radar and lightning datasets routinely used in operations, and 3) how can AACP recognition be used for severe storm forecasting/warning in conjunction with other conventional data? Although model simulations have been used in many studies to understand AACP-producing storm dynamics (Wang 2003; Wang et al. 2016; Homeyer et al. 2017), developing the link between AACPs, radar-derived storm dynamics, and severe weather has been challenging because 1) there is no existing database of AACP events that provides critical details on plume start and end times, in part because there is no robust, automated way to identify AACPs, and 2) development of accurate radar-based cell track datasets over broad geographic regions encompassing entire storm lifetimes is challenging.

Severe weather warnings are normally based on inferences of hail, damaging wind, or tornadoes derived from Doppler weather radars, recently augmented by dual-polarization observations across the United States. The U.S. Next Generation Weather Radar (NEXRAD) network often can directly detect severe weather conditions such as high winds, high reflectivity, and polarimetric signatures of hail, as well as the presence of rapid rotation within storms linked to mesocyclones and tornadoes.
Therefore, a forecaster is often not analyzing satellite imagery after a storm develops a prominent radar echo. But there may now be an opportunity for new imagery and derived products from the GOES-R satellite series (Schmit et al. 2005; Goodman et al. 2013) and patterns within this imagery such as the AACP to raise situational awareness and increase confidence that a storm could be severe. Given that AACPs occur in many regions without radar coverage, warnings based on early recognition of an AACP could help save lives and property.

\section{d. Objectives of this study}

In an effort to quantify and better communicate the significance of the AACP signature, this paper presents an analysis of 405 AACP-producing storms identified across 13 severe weather days observed by GOES-14 and GOES-16 30-s to 1-min super rapid scanning. Over 8000 GOES images were analyzed by a team of human experts to estimate AACP start and end times at the individual storm scale. Tracking of both the 405 AACP-producing storms and over 4000 storms without AACPs during their entire lifetime was accomplished using NEXRAD data postprocessed with the GridRad system (Homeyer and Bowman 2017). Through fusion of GridRad and super rapid scan GOES datasets, severe weather reports, and National Weather Service (NWS) severe weather warning information, we will address the following questions:

1) What radar-observed dynamical processes trigger and sustain an AACP?

2) What is unique about AACP storms relative to nonAACP storms?

3) What is the severe weather frequency for AACP storms compared to non-AACP storms?

4) Are certain severe weather types more likely to be produced by AACP storms?

5) How far in advance do AACPs occur ahead of severe weather?

6) What is the relationship between AACP storms and supercells? What is unique about supercells that do not produce AACPs?

7) How can severe weather warning be augmented by knowledge of the presence of an AACP?

Section 2 will describe the datasets and methods used in this study, section 3 will present results, and section 4 will discuss and summarize the findings.

\section{Datasets and methods}

\section{a. GridRad data}

NEXRAD level II (i.e., volume) data were retrieved from the National Centers for Environmental Information (NCEI) for the 13 events described in Table 1. 


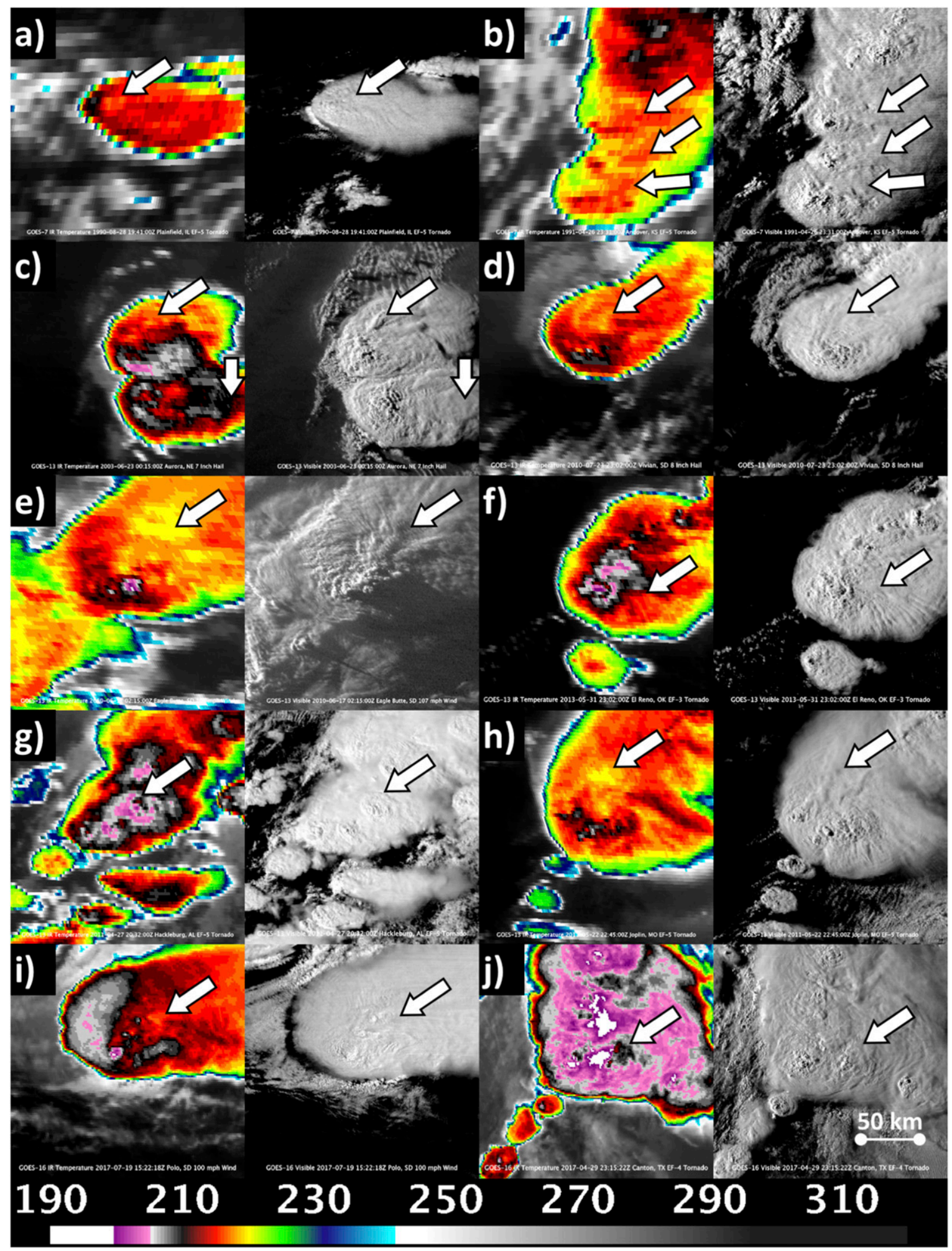

FIG. 2. GOES visible and IR images of significant severe storms over the United States: (a) 28 Aug 1992, Plainfield, IL, EF5 tornado; (b) 26 Apr 1991, Andover, KS, EF5 tornado; (c) 23 Jun 2003, Aurora, NE, 18-cm (7 in.) hail; (d) 23 Jul 2010, Vivian, SD, 20-cm (8 in.) hail; (e) 17 Jun 2010, Eagle Butte, SD, $47.8 \mathrm{~m} \mathrm{~s}^{-1}\left(107 \mathrm{mi} \mathrm{h}^{-1}\right)$ measured wind gust; (f) 31 May 2013, El Reno, OK, EF3 tornado; (g) 27 Apr 2011, Hackleberg, AL, EF5 tornado; (h) 22 May 2011, Joplin, MO, EF5 tornado; (i) $19 \mathrm{Jul} \mathrm{2017,} \mathrm{Polo,} \mathrm{SD,} 44.7 \mathrm{~m} \mathrm{~s}^{-1}$ (100 mi h${ }^{-1}$ ) measured wind gust; and (j) 29 Apr 2017, Canton, TX, EF-4 tornado. Observations are from GOES-7 in (a) and (b), GOES-13 in (c)-(h), and GOES-16 in (i) and (j). The arrows identify where IR warm anomalies or textures within plumes were most evident. 


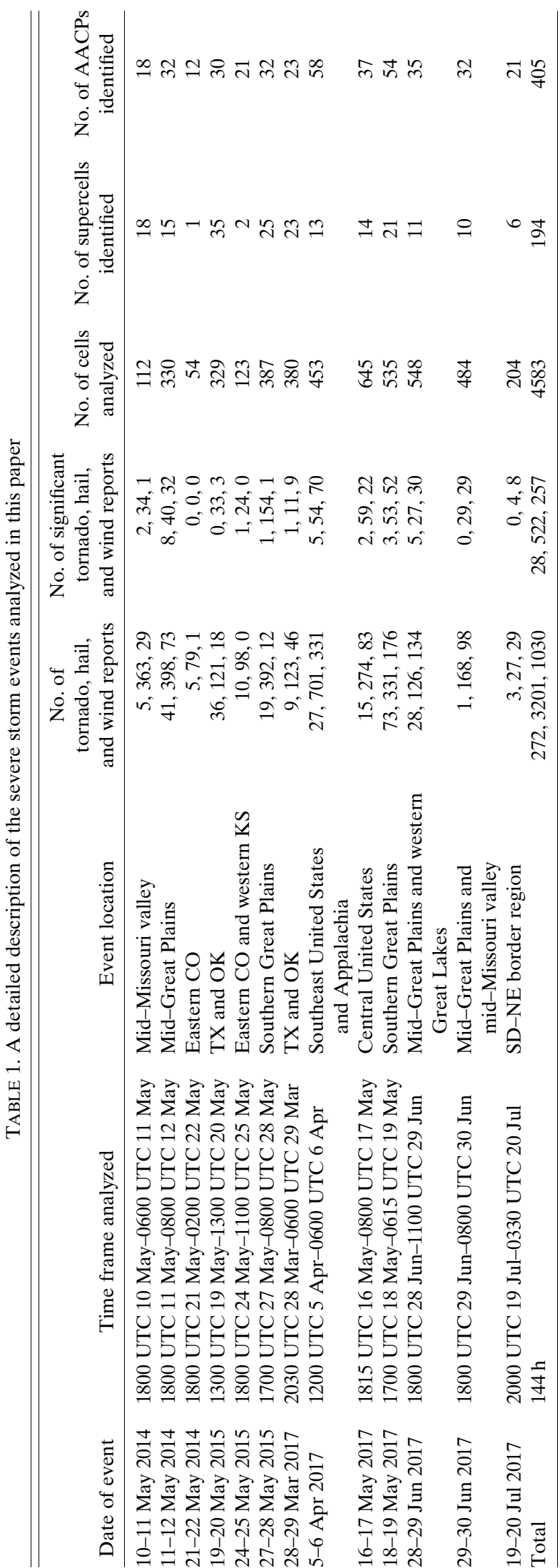

The NEXRAD network consists of more than 100 WSR-88D S-band (10-11-cm wavelength) radars that observe clouds and precipitation on a polar grid in range, azimuth, and elevation relative to the location of the radar. All NEXRAD observations used in this study were obtained at a range resolution of $250 \mathrm{~m}$, an azimuthal resolution of $0.5^{\circ}$ for the lowest $3-4$ elevations and $1.0^{\circ}$ otherwise, and typically at 14 elevations per volume. The radar data were processed using the four-dimensional space-time merging methods described by Homeyer and Bowman (2017, and references therein), which provide volumes of the radar variables at $2-\mathrm{km}$ horizontal resolution, 1-km vertical resolution, and 5-min temporal resolution over the extent of each GOES Super Rapid Scan domain. This radar dataset is referred to as GridRad and more information on the dataset is available online (http://gridrad.org). A three-dimensional rendering of a GridRad radar reflectivity volume featuring hailstorms over north Texas (corresponding to the GOES-16 image in Fig. 4d) is shown in Fig. 3. Three distinct updrafts coincident with the coldest GOES-16 IR BT are evident (Fig. 4d), with the southernmost being the deepest and composed of $60-\mathrm{dB} Z$ echoes that reach an $11-\mathrm{km}$ altitude.

Analyses of all datasets on an individual storm (i.e., "cell") basis in this study was facilitated through objective radar-based storm tracking. Individual storm tracks were computed throughout each event using an echo-top algorithm described by Homeyer et al. (2017). For this study, tracking is accomplished through time linking of $40-\mathrm{dB} Z$ echo-top maxima, filtered by the convective echo classification output by the Storm Labeling in 3 Dimensions (SL3D) algorithm (Starzec et al. 2017). The objectively tracked storms were reviewed to manually identify and merge discontinuous tracks that correspond to the same storm. Comparisons of GridRad storm tracks with those from the NOAA Severe Weather Data Inventory (SWDI; section 2d) show consistent results (e.g., see Fig. 3 in Homeyer et al. 2017). The quality-controlled storm tracks were then used to extract maximum (or minimum in the case of IR temperature) values from each dataset within a $10-\mathrm{km}$ radius of the storm location at 1-min intervals, with observations made at a coarser resolution than 1-min interpolated linearly in space and time to the storm track location. Additional details on the object tracking and data fusion approach are provided by Homeyer et al. (2017) and T. Sandmæl et al. (2018, unpublished manuscript).

Supercell storms were identified using GridRad observations for all 13 severe weather days via a combination of objective and subjective methods (Sandmæl 2017). First, potential supercell storms were objectively identified by searching for storm tracks with 


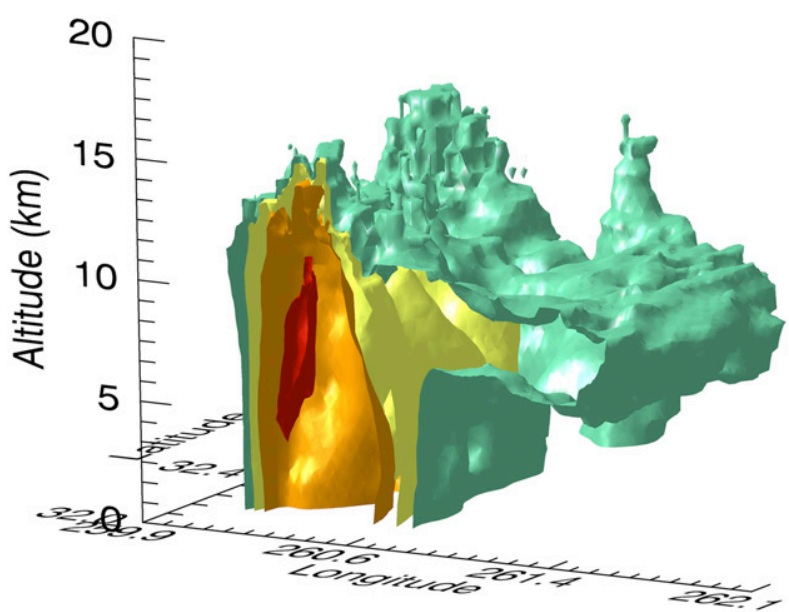

FIG. 3. A 3D volume rendering of GridRad reflectivity at horizontal polarization for three hailstorms over north Texas at 2230 UTC 18 May 2017, corresponding to the GOES-16 image shown in Fig. 4d. A vertical slice through the updraft of the southernmost cell shows that high reflectivity values corresponding to graupel and/or hail $(60 \mathrm{dBZ}$; red) reach up to $11 \mathrm{~km}$ in altitude within the intense updraft core.

long duration ( $\geq 60 \mathrm{~min}$ ); strong azimuthal shear (or rotation, $>3.5 \times 10^{-3} \mathrm{~s}^{-1}$ ), which helps to discriminate between nonrotating or weakly rotating storms and supercells (e.g., see Fig. 3 in Sandmæl et al. 2018); and tall 40 -dBZ echo tops ( $\geq 12 \mathrm{~km}$ during any point in a storm's life cycle). Objectively selected candidate storms were then subjectively evaluated to confirm or deny supercellular characteristics. In particular, in order to classify a storm as a supercell, the following conditions were sought: 1) obvious deviant motion relative to neighboring storms, 2) a hook echo at altitudes $\leq 3 \mathrm{~km}$, 3 ) a bounded weak-echo region apparent in upper-level maps or vertical sections of radar reflectivity, or 4) polarimetric signatures such as the differential reflectivity arc at low levels (Fujita 1958; Browning and Donaldson 1963; Lemon and Doswell 1979; Doswell and Burgess 1993; Kumjian and Ryzhkov 2008). If at least two of these conditions were met, the storm was categorized as a supercell. This classification method identified 194 supercells across the 13 events. This method may miss some weak supercells as well as supercells embedded within organized convective systems, but all tornadic storms and AACP-producing storms (regardless of whether or not they passed the initial objective duration, shear, and tall echo-top identification) were evaluated to confirm supercell or nonsupercell characteristics.

\section{b. GOES observations}

GOES-14 and GOES-16 imagery collected at intervals from 30-s to 1-min were acquired from the University of Wisconsin-Madison Space Science and Engineering
Center using the Man computer Interactive Data Access System (McIDAS-X) software package (Lazzara et al. 1999). GOES-16 collects these rapid observations when operating in "flex mode." While in flex mode, GOES-16 can observe two geographically distinct domains every minute, or a single domain every $30 \mathrm{~s}$, while also observing a contiguous United States (CONUS) domain at 5-min intervals and hemispheric "full disk" domain at 15-min intervals. Portions of the 28 March, 5 April, and 16 May 2017 events were observed at 30-s intervals, but this did not bias the analyses as 1-min data are sufficient for AACP identification. Over 8000 GOES images were analyzed to find all AACP signatures that occurred throughout the 13 events. The 1-min or better imagery will be referred to generically as "super rapid scan imagery" for the remainder of this paper. It is possible to identify AACPs in 5-30-min data collected by previous- and current-generation GEOsats. However, 1-min super rapid scan data are optimal for 1) identifying plumes, which can sometimes be subtle and short lived (see Fig. 5 to be discussed later), and 2) determining the start and end times of plume production for comparison with radar- and lightning-derived products, severe weather reports, and severe weather warnings.

GOES-16 datasets include $0.5 \mathrm{~km}$ per pixel $0.64-\mu \mathrm{m}$ visible channel imagery, $2 \mathrm{~km}$ per pixel $10.3-\mu \mathrm{m}$ channel IR window channel imagery, and a quantification of texture evident in OT regions in visible imagery (Bedka and Khlopenkov 2016). For the 29-30 June 2017 event, $10.3-\mu \mathrm{m}$ channel data were unavailable so the $11.2-\mu \mathrm{m}$ channel was used instead. The $11.2-\mu \mathrm{m}$ channel is slightly more sensitive to water vapor than the $10.3-\mu \mathrm{m}$ channel "clean window," but the signature of an AACP is essentially the same in these two channels. The GOES-16 imagery analyzed in this paper is considered "preliminary and preoperational" because it was collected during a year-long postlaunch testing phase. Although the data were preliminary, they were still of high quality and suitable for AACP identification. GOES-14 datasets include $1 \mathrm{~km}$ per pixel $0.65-\mu \mathrm{m}$ visible channel imagery and $4 \mathrm{~km}$ per pixel $10.7-\mu \mathrm{m}$ channel infrared window channel imagery. Although Fig. 2 shows that AACPs could be identified even in $10+\mathrm{km}$ per pixel GOES-7 imagery, the higher spatial detail provided by GOES-16 enables more reliable AACP identification. Image resolution would not impact identification of a prominent AACP, but some subtle AACPs of unknown number may have been missed in the GOES-14 analyses.

\section{c. Earth Networks Total Lightning Network}

The Earth Networks Total Lightning Network (ENTLN) detects lightning using pulses in vertical electric field measurements from parts of the $1-\mathrm{Hz}-12-\mathrm{MHz}$ 


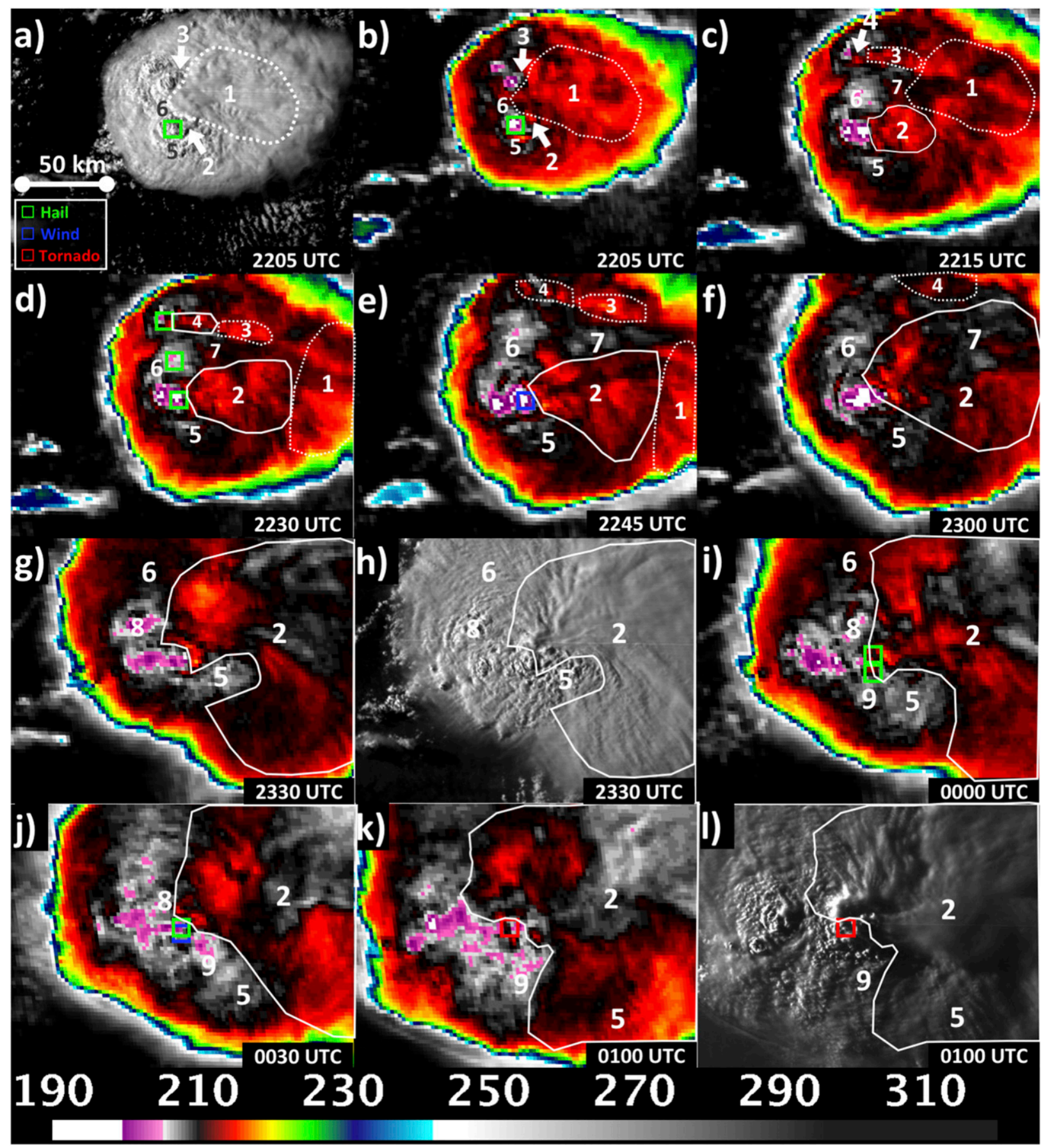

FIG. 4. A time series of GOES-16 visible and IR temperature images throughout the lifetime of a long-lived supercell storm in northcentral Texas. Images are centered on the primary updraft core of the storm as it moved eastward and generated several instances of severe hail up to $6.4 \mathrm{~cm}$ (2.5 in.) in diameter, damaging wind, and an EF1 tornado, denoted by colored boxes [see legend in (a)]. Severe weather reports from other storms in the domain are also denoted. Visible images are provided (a) at 2205 UTC, the time when the first AACP was generated by these storms; (h) at 2330 UTC, the middle of the storm lifetime when the AACP was warmest; and (l) at 0100 UTC, near sunset. A variety of features in the images are annotated with numbers 1-9 and discussed in the text. Solid lines indicate AACPs that are being actively generated at the time of the image. Dotted lines indicate residual plume material from older updrafts that have decayed. 


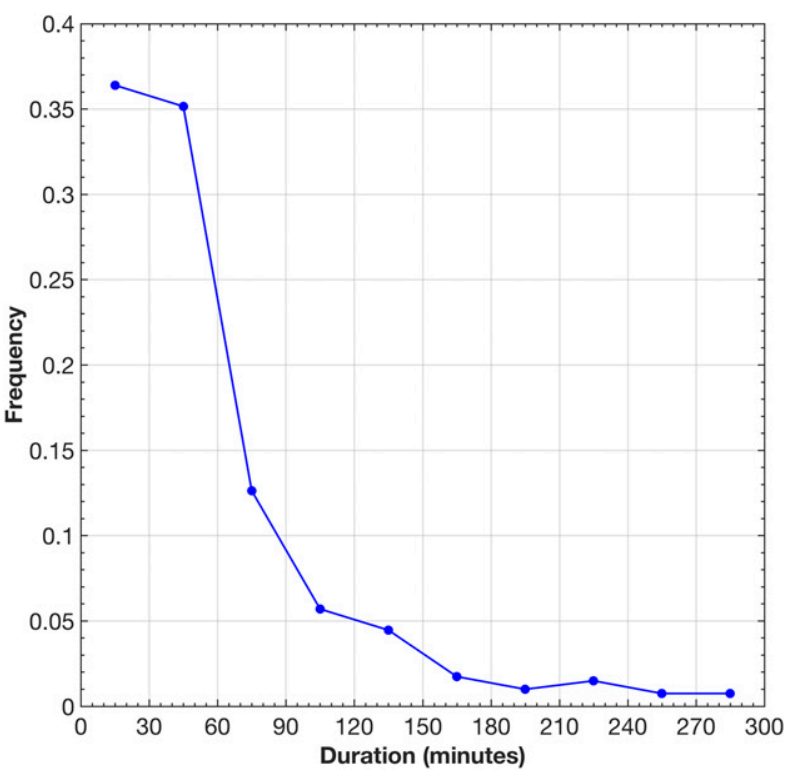

FIG. 5. AACP production duration per storm, expressed in terms of frequency relative to the total population of 405 AACP storms.

frequency range from over 700 sites across the contiguous United States (Liu and Heckman 2010). Individual pulses are located in space and time by statistically solving overdetermined electrical signal time-of-arrival equations using measurements from at least five stations. Sources close together in space and time are grouped into flashes, which are accumulated in 1-min intervals into $0.08^{\circ} \times 0.08^{\circ}$ longitude-latitude density grids (an area of $\sim 64 \mathrm{~km}^{2}$ ) to emulate what could be provided by the GOES-16 Geostationary Lightning Mapper (Goodman et al. 2013) once the data become fully operational. The maximum of the total lightning flash rate was extracted along each storm track for analysis in this study, which consists of both cloud-to-ground and intracloud flashes.

\section{d. North American Regional Reanalysis}

The North American Regional Reanalysis (NARR) is a 3-hourly product produced by the NOAA/National Centers for Environmental Prediction (NCEP) with a 32-km horizontal grid spacing and 45 vertical layers covering the period from 1979 to the present (Mesinger et al. 2006). NARR data are used to define the tropopause temperature and height in order to normalize GOES IR BTs and GridRad echo-top heights across the 13 events analyzed in this study. Although the authors are not aware of a publication discussing the accuracy of NARR tropopause estimates, a recent analysis of the ERA-Interim tropopause relative to radiosondes showed that $\sim 77 \%$ of heights agree within $\pm 0.5 \mathrm{~km}$, and $\sim 91 \%$ of points agree within $\pm 1 \mathrm{~km}$ (comparable to the vertical resolution of the model; Solomon et al. 2016).
Similar accuracy is provided by the NCEP Global Forecast System and appears to be a common characteristic of numerical models (Homeyer et al. 2010). The NARR most unstable convective available potential energy (CAPE) and effective bulk shear (e.g., Thompson et al. 2007) are used to characterize instability and wind shear environments near nonsevere non-AACP storms, severe non-AACP storms, supercells, and AACP storms.

\section{e. NCEI Severe Weather Data Inventory}

The NCEI hosts the SWDI storm event database that contains the time, duration (if available), location, magnitude, and source of all confirmed U.S. severe weather reports. Avenues of reporting include but are not limited to NOAA/NWS storm surveys, trained spotters, and law enforcement. This study uses the SWDI reports to define severe weather events. While other report databases exist such as from the NOAA/ SPC, the SWDI undergoes more rigorous quality control and contains more report sources than other databases. For this analysis, SWDI reports are linked with storm tracks if they occur within $10 \mathrm{~km}$ of a storm's location at the time the report is valid.

Although the NCEI database provides the most comprehensive account of historical severe weather events in the United States, well-established reporting biases inherent to the database influence the severe weather relationships and lead time presented in this study (Doswell et al. 2005; Trapp et al. 2005, 2006; Verbout et al. 2006; Brotzge et al. 2011). Fewer reports are available in sparsely populated areas and during nighttime hours when most people are asleep. An unreported severe weather event could artificially decrease statistics defining how often severe weather is generated by AACP (and nonAACP) storms, and also inflate the time interval that an AACP appears before severe weather. Use of radarderived severe weather indicators such as the maximum expected hail size (MEHS; Witt et al. 1998) or rotation tracks (Smith et al. 2016) could be used as a stable and more unbiased proxy for severe reports. Analysis of AACP storms with respect to these proxies is a topic of ongoing work by the authors of this paper.

\section{f. National Weather Service Severe Weather Warning Archive}

NWS severe thunderstorm and tornado warnings are used to determine if advanced notice of severe weather could be provided by AACP appearance prior to warning issuance time. These data were obtained through an online archive, hosted by the Iowa Environmental Mesonet (IEM), which is a volunteer effort based out of Iowa State University (Iowa State University 2018a). The database includes the time of issuance, time of expiration, and 
coordinates of the polygon for each severe thunderstorm and tornado warning issued by the NWS. Warnings were linked with storm tracks if the storm passed through the polygon during valid warning times (i.e., any time between issuance and expiration). Most warnings also feature a maximum wind gust and/or hail size "tag" expected during the warning time period, if wind or hail were expected to occur. No information on expected intensity of a tornado via the EF scale is provided.

\section{g. Plume identification}

GOES visible and IR imagery were animated and analyzed using the McIDAS-V software package (Achtor et al.2008) to determine the starting and ending time of AACP production by an individual storm updraft. AACP identification was based on IR imagery and supplemented by visible imagery when available. The identification process was subjective, guided by the extensive image analysis experience of the authors described by Setvák et al. (2013), Homeyer (2014), Bedka et al. (2015), and Homeyer et al. (2017). Discussion on AACP temporal evolution and challenges associated with their identification is provided in section 3a. Over $70 \%$ of AACPs were generated for less than $1 \mathrm{~h}$ but eight storms ( $\sim 2 \%$ of the population) produced a continuous AACP for more than $4 \mathrm{~h}$ (Fig. 5). The distribution of AACP duration is similar to the enhanced-V events analyzed by McCann (1983).

\section{h. Analysis methods and data fusion}

The 13 events analyzed in this study featured some of the most diverse and widespread severe storms observed by GOES in super rapid scan mode. These events include all types of severe weather and convective modes including weak (or shallow) convection, discrete cells and supercells, squall lines, and mesoscale convective systems. In total, 4503 severe weather reports were collected within the geographic domains observed by GOES super rapid scanning. These reports include $28 \mathrm{EF} 2$ tornadoes, 257 wind gusts of $33.4+\mathrm{m} \mathrm{s}^{-1}\left(74.8+\mathrm{mih}^{-1}\right)$, and 522 reports of $5-\mathrm{cm}^{-}(2+$ in.) diameter hail (see Table 1), denoted in the text as "significant severe weather" reports (Hales 1988). Two events (21-22 May 2014 and 19-20 July 2017) were selected because of the presence of exceptionally long-lived supercells, while the remaining events featured more widespread severe weather. We had limited knowledge of the satelliteobserved characteristics of severe storms during these events. Any knowledge of the cases prior to completing the analysis was derived from cursory glances at GOES imagery at random times during some of these events, which did not bias our event selection or artificially enhance the AACP-severe weather relationships.
GridRad storm track data are used to identify the storm cell ID number corresponding to the AACPproducing updraft. Satellite imagery of convection can be complex, especially when rapid storm decay and generation of a new cell occurs in close proximity, both in an area of cold IR BT. Therefore, it is sometimes difficult to ensure that one is monitoring the same cell in a sequence of images. Understanding updraft, cloudtop height, and severe weather characteristics before, during, and after an AACP represent some of the core science goals of this study, so ensuring that we correctly associate an AACP with its parent updraft is critical. Pairing the GridRad storm tracks with GOES data reduces uncertainty. GridRad storm tracks were corrected for parallax based on the 10-dBZ echo-top height for collocation with GOES data. A variety of GOES, Grid-Rad, and ENTLN parameters were accumulated at 1-min intervals within $10 \mathrm{~km}$ of the storm track, and the most extreme value (maxima for most parameters except IR temperature) were recorded for analysis.

Plume lifetime was determined by identifying the sustained emission of warm and/or textured cloud material from an OT region along the same GridRad storm track. An AACP must be produced continuously for $10+\min$ to be considered in this analysis. GOES data must be available throughout the lifetime of the storm for an AACP to be included in the database, though GOES image outages of up to $5 \mathrm{~min}$ were accepted. Occurrences of an AACPproducing cell changing ID number due to brief cell decay, splitting, or other complex reasons were noted. Most cells continuously produce an AACP for a period of time and then decay or, in the case of a supercell, split into two cells that may each produce their own AACP. In some situations, a cell will produce an AACP for some time, then production stops while a strong radar echo persists. The cell can then restart plume production at some later time. All time periods of active plume production are noted in these instances. When updraft cores are close to one another and rapidly evolving, as often occurs in mesoscale convective systems (MCS), cell IDs may change more frequently than would otherwise be expected. AACP production can be brief in these instances and challenging to link to an individual GridRad storm track.

It is typically clear when plume production stops. In particular, an OT region disappears and the warm, textured AACP detaches from the OT and advects downstream. An AACP and associated warm anomaly (if present) can be evident for several hours after production ceases (see Figs. 4a,b), but postproduction persistence is not of interest to this study. As described by Smith et al. (2017) and Homeyer et al. (2017), the AACP eventually sublimates, leading to significant increases in upper troposphere-lower stratosphere (UTLS) water 
11 May 2014

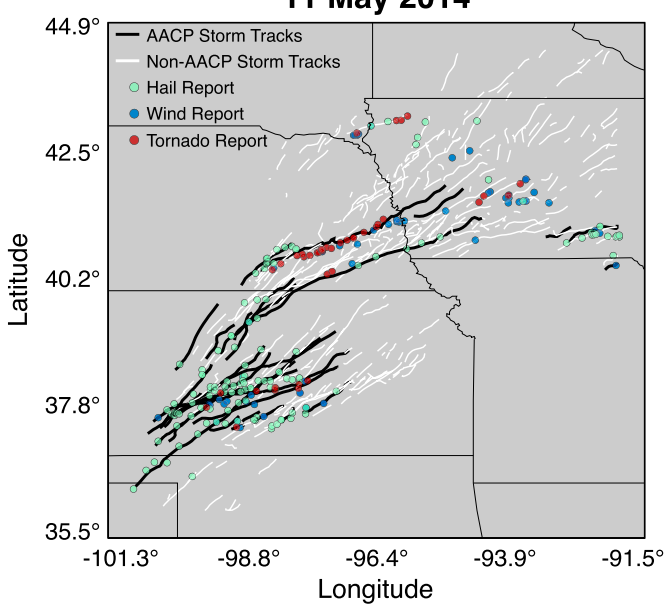

5 April 2017

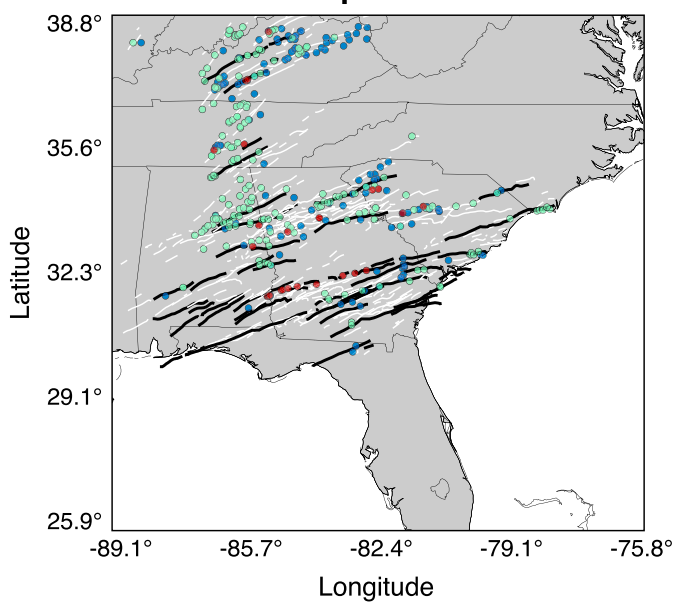

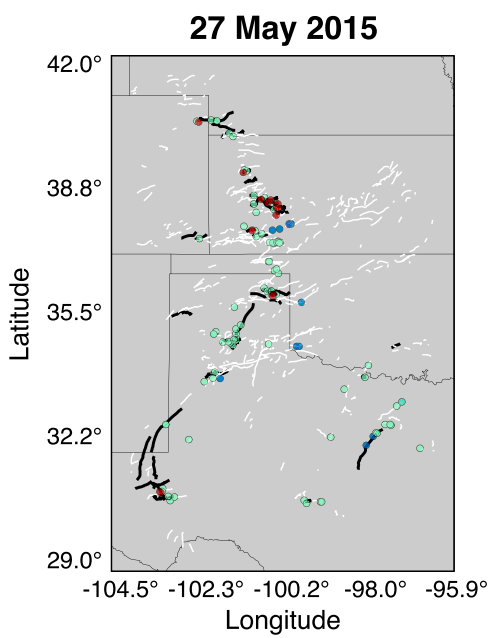

16 May 2017

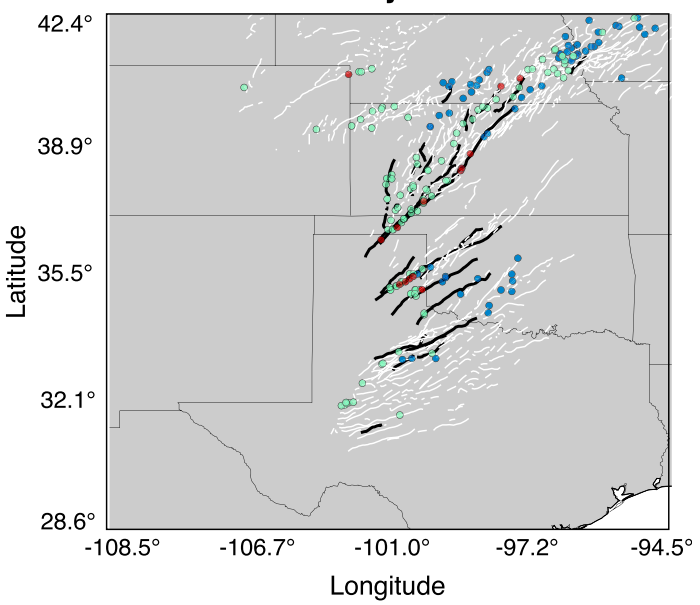

FIG. 6. GridRad AACP (black) and non-AACP (white) storm tracks for (top left) 11-12 May 2014, (top right) 27-28 May 2015, (bottom left) 5-6 Apr 2017, and (bottom right) 16-17 May 2016, overlaid with SWDI severe weather reports (colored circles; see legend in top-left panel).

vapor that, when aggregated across many events, can measurably impact stratospheric composition (see Anderson et al. 2017 and references therein).

A total of 405 AACP-producing storms were tracked across the 13 events in addition to 4178 other non-AACP storms. GOES- and GridRad-derived characteristics of AACP storms before, during, and after AACP production are extracted for analysis. Examples of AACP and non-AACP storm tracks and severe weather reports for 4 of the 13 events are shown in Fig. 6. Severe weather frequency and type throughout AACP storm lifetimes is also evaluated and contrasted with non-AACP storms. Relationships between AACPs and supercells are also derived to determine if the AACP can be used to identify a supercell and to contrast supercells with and without AACPs. Finally, the timing of AACP appearance relative to the first severe weather report and first
NWS severe thunderstorm or tornado warnings is calculated. The relationship between AACPs, NWS warnings, and significant hail is also explored to determine if an AACP detection could increase warning confidence that significant hail will occur.

\section{Results}

\section{a. AACP characteristics and temporal evolution}

Experience with AACP identification during this study indicates that most AACPs can be identified by warm IR BTs and visible texture, but an AACP is not always warm throughout its lifetime and BT/texture patterns can be quite complex with storm tops. The Córdoba storm in Fig. 1 features an AACP BT about $18 \mathrm{~K}$ warmer than the OT minimum BT in pixels directly adjacent to the OT (yellow pixels). Heymsfield et al. (1983) hypothesized 
that warming adjacent to the OT was generated by subsidence along the descending branch of a breaking gravity wave, which he called the "close-in warm area," a signature also evident in Figs. 4g and 4h. Fujita (1974) referred to this area as the "warm trench." Much of the AACP that extends over $150 \mathrm{~km}$ to the east of the northern Córdoba storm is as cold as the surrounding tropospheric anvil. The southern storm features a comparable anvil temperature and an OT minimum BT that is only $2.5 \mathrm{~K}$ warmer than the northern storm, but with a warm AACP rather than cold. The AACP visible texture in the northern storm is more prominent, which suggests increased cloud optical depth and/or height penetration above the anvil. The rawinsonde temperature profile in the UTLS layer is complex, with evidence of several inversion layers above $12 \mathrm{~km}$ (University of Wyoming 2018). Matching the temperature of an AACP with the rawinsonde temperature yields highly uncertain height estimates for these two storms; the northern hailstorm AACP (210-K BT) would be assigned either a 15.4- or 20-km altitude and the southern storm (218-K BT) would be assigned either 12.6 or $23.5 \mathrm{~km}$. The difference in AACP orientation, from northwest to southeast in the northern storm and from southwest to northeast in the southern storm, is caused by the deviant right motion of the southern storm (i.e., a "right moving" supercell), whereas the northern storm exhibits deviant left motion (i.e., a "left moving" supercell). These differing cell motions induce different storm-relative wind and outflow patterns, and perhaps also different gravity wave dynamics that could affect the IR BT pattern in each storm (Lindsey and Bunkers 2005).

Figure 4 shows an annotated GOES-16 time series of a long-lived supercell, centered on the supercell OT region, that exemplifies the complex evolution of severe storm cloud tops. At 2205 UTC (Figs. 4a,b), a residual AACP generated by a previous updraft (region 1) is evident via visible texture and warm BT. Two new AACPs are being generated at this time (regions 2 and 3 ). The storm that generates the region $2 \mathrm{AACP}$ is the primary storm of interest in subsequent panels. The cold "arms" of an evolving enhanced-V pattern are denoted by regions 5 and 6 . The arms are caused by anvil-level (15-km altitude) wind flow that is forced around the OT region that has a peak GridRad 10-dBZ echo-top height of $18-19 \mathrm{~km}$ (not shown), similar to what occurs with wind flow around isolated mountain peaks (Smith 1980). Air is forced upward slightly because of the interaction with the OT obstacle, causing colder IR BTs in the arms than the downstream anvil.

At 2215 UTC (Fig. 4c), the updraft that had generated the AACP in region 3 decayed and residual warm cloud moved eastward. Another updraft developed behind region 3 that also generated a short-lived AACP (region 4). Region 1 became slightly colder and continued to move eastward. The arms of the enhanced $\mathrm{V}$ continued to grow and some cold cloud from the region 6 arm wrapped around to the north of the region $2 \mathrm{AACP}$ (region 7). The region 6 enhanced-V arm converged with the decayed OT that generated the region $3 \mathrm{AACP}$ (magenta color). Hail was reported in this area near 2230 UTC (Fig. 4d). The region 2 and 4 AACPs continued to grow at 2230 UTC. The region 3 AACP maintained its warm BT. The region $1 \mathrm{AACP}$ is difficult to track as it is overtaken by the large region 2 AACP. At 2245 UTC (Fig. 4e), the OT that generated region 4 decayed, leaving warm cloud that moved northward. Region 7 became slightly colder at 2245 UTC and was overtaken by region 2 at 2300 UTC (Fig. 4f).

At 2330 UTC, the area of coldest cloud was elongated from east to west (Fig. 4g). The supercell split prior to this image and generated a left-moving cell (region 8, magenta IR BT) that later became reabsorbed by the primary storm after 0030 UTC. Cold cloud in the southern arm (region 5) persisted and seemingly diverted the region 2 AACP. Plume cloud along the eastern edge of the domain is cold. Areas of northwest-southeast-oriented transverse banding (Lenz et al. 2009) comprise the warm portion of the AACP. The warmest BT within the AACP's lifetime occurred at this time. It is unclear why the temperature is so warm within the banded cloud, but it may indicate stronger lofting of cirrus during a wave breaking event.

At 0000 UTC, a second surge of cold cloud develops on the southern arm (region 9) but, unlike region 8 , is not associated with a convective core in radar observations. The precipitation structure of the primary cell continued to elongate at 0030 UTC but the highest echo top $(18-19 \mathrm{~km})$ remained on the eastern edge where the region $2 \mathrm{AACP}$ was continuously generated. The region 5 arm became indistinguishable within region 2 . At 0100 UTC, the region 2 AACP becomes entirely cold for unknown reasons.

Hypotheses for cold AACPs include 1) sedimentation of large ice crystals that reduces the cloud optical depth, allowing a colder tropospheric anvil beneath the AACP to dominate the radiative signal; 2) AACP injection into nearly isothermal UTLS environments or above-anvil layers that are cooling with height; 3 ) plume subsidence into layers with colder temperature; and/or 4) cooling of the local UTLS temperature through AACP sublimation. From our experience, a storm rarely produces only a cold AACP. That is, an AACP is warm in some portion of the plume, especially adjacent to the OT, or at some point during the storm lifetime. At night, there is increased uncertainty in the AACP duration of unknown magnitude given the absence of visible imagery. An AACP is 
identified at night in this study by identifying a warm area adjacent to the OT and a narrow corridor of "plume shaped" outflow that is continuously emitted from the OT region. AACP production ends when the OT dissipates, and the outflow channel is no longer being actively emitted. Figure 4 and the Córdoba storm (Fig. 1) demonstrate that severe weather can be generated by a storm regardless of AACP temperature. These cases and many others throughout the literature illustrate the many challenges associated with physical interpretation of AACP BTs and the benefits of super rapid scan, multispectral imagery for plume identification.

Previous studies indicate that some AACPs are more reflective than the primary anvil in near-IR $(\sim 1.6$ and $2.2 \mu \mathrm{m})$ and shortwave-IR $(\sim 3.9 \mu \mathrm{m})$ imagery, suggesting that they are composed of small ice crystals (Setvák and Doswell 1991; Levizzani and Setvák 1996; Rosenfeld et al. 2008). A 1.6- $\mu \mathrm{m}$ image of the two aforementioned Argentina storms (Fig. 1c) shows no evidence of enhanced reflectance within their AACPs. The AACPs feature the same color shading in this image as the anvil, which suggests comparable particle size. The EUMETSAT severe convection red-green-blue (RGB) approach (EUMETSAT 2018; Fig. 1d) combines information from visible, near-IR, water vapor absorption, and IR window channels to emphasize severe convection with strong updrafts and small ice particles. Enhanced 3.9- $\mu \mathrm{m}$ reflectance due to small ice crystals would produce a yellow color in this RGB composite. The OT regions in both Argentina storms do exhibit a yellow color, but no yellow or small ice crystals are found within the AACPs. Further research is required to better understand variations in AACP microphysics depicted by these satellite observations.

\section{b. NEXRAD, ENTLN, and GOES-derived properties of AACP and non-AACP storms}

A set of GOES, ENTLN, and GridRad-derived parameters for AACP and non-AACP storms are analyzed here to show differences between the two storm populations, and the evolution of these parameters within periods before, during, and after AACP production. The analyses are presented in the form of boxand-whisker diagrams shown in Figs. 7 and 8 . GridRad echo-top heights and GOES IR BTs are normalized by the tropopause height or temperature to enable comparison across the 13 storm events included in this study. The GridRad storm peak $10-\mathrm{dB} Z$ echo top $\left(Z_{10-\mathrm{dB} Z}\right.$; Fig. 7a) approximates the height of the physical cloud top (Cooney et al. 2018), and $Z_{10-\mathrm{dB} Z}$ will reach or exceed the tropopause height only in the presence of convective updrafts. The median $Z_{10-\mathrm{dB} Z}$ during AACP production is $\sim 1.5 \mathrm{~km}$ higher than during non-AACP storms. Severe non-AACP storms also have slightly higher tops $(0.5 \mathrm{~km})$ compared to nonsevere cells, but this difference is within the $1-\mathrm{km}$ uncertainty of the GridRad product. An AACP storm at times prior to and also after AACP production is largely indistinguishable from a non-AACP severe storm. As expected, the $Z_{10-\mathrm{dB} Z}$ rises as a plume is generated and drops after the plume is no longer produced. The whiskers of the distribution show that non-AACP storms can reach comparably extreme $Z_{10-\mathrm{dB} Z}$ values relative to AACP storms. This indicates that high cloud tops alone are not necessarily a good discriminator of intense and severe convection, a conclusion supported by similar results from GOES IR BTs (Fig. 8c). The cloud tops of storms with trackable (i.e., temporally persistent) $40-\mathrm{dB} Z$ echoes often reach and penetrate the tropopause, but AACP storm updrafts penetrate the tropopause by a greater margin. A quarter of the echo-top distribution is below the tropopause during AACP production, which could be due to a combination of 1) brief updraft decay and plume cessation embedded within what appeared to be a long-duration plume to the human analysts and/or 2) $Z_{10-\mathrm{dB} Z}$ uncertainty determined to be on the order of $1 \mathrm{~km}$ (Cooney et al. 2018).

Additional inferences of updraft intensity are provided by the GridRad $Z_{40-\mathrm{dB} Z}$ and upper-level (altitude of $8+\mathrm{km}$ ) radial divergence, as well as lightning flash rate. Since terminal velocities increase with increasing particle size, high $Z_{40-\mathrm{dB} Z}$ within a storm implies stronger vertical velocities than storms with lower $Z_{40-\mathrm{dB} Z}$ (in a relative sense) because strong velocity is required to loft large hydrometeors to high altitudes. Strong radial divergence also indicates rapid outflow from an intense updraft. The $Z_{40-\mathrm{dB} Z}$ for severe non-AACP storms is higher than that from nonsevere, non-AACP storms by a greater margin than what is depicted by the $Z_{10-\mathrm{dB} Z}$ field. This further suggests that updrafts in severe storms are stronger than nonsevere storms (Fig. 7b). Periods prior to and after AACPs are again similar to nonAACP severe storms in terms of $Z_{40-\mathrm{dB} Z}$ and, to a lesser extent, radial divergence (Fig. 7c). These results suggest that the updraft accelerates as an AACP is produced, as evidenced by the $2-3-\mathrm{km}$ increase in median $Z_{40-\mathrm{dB} Z}$ during AACP production. Severe AACP storms are of exceptional intensity based on $Z_{40-\mathrm{dB} Z}$ and divergence metrics. ENTLN lightning flash rates within AACP storms are about double the rate of that from nonAACP storms (Fig. 8a). Lightning has been shown to increase significantly prior to severe weather in previous studies, termed a "lightning jump" (Schultz et al. 2009, 2011). Enhanced flash rates for AACP storms are not surprising given the sharp rise of $Z_{40-\mathrm{dB} Z}$ that occurs when an AACP is present, and the fact that the $Z_{40-\mathrm{dB} Z}$ 

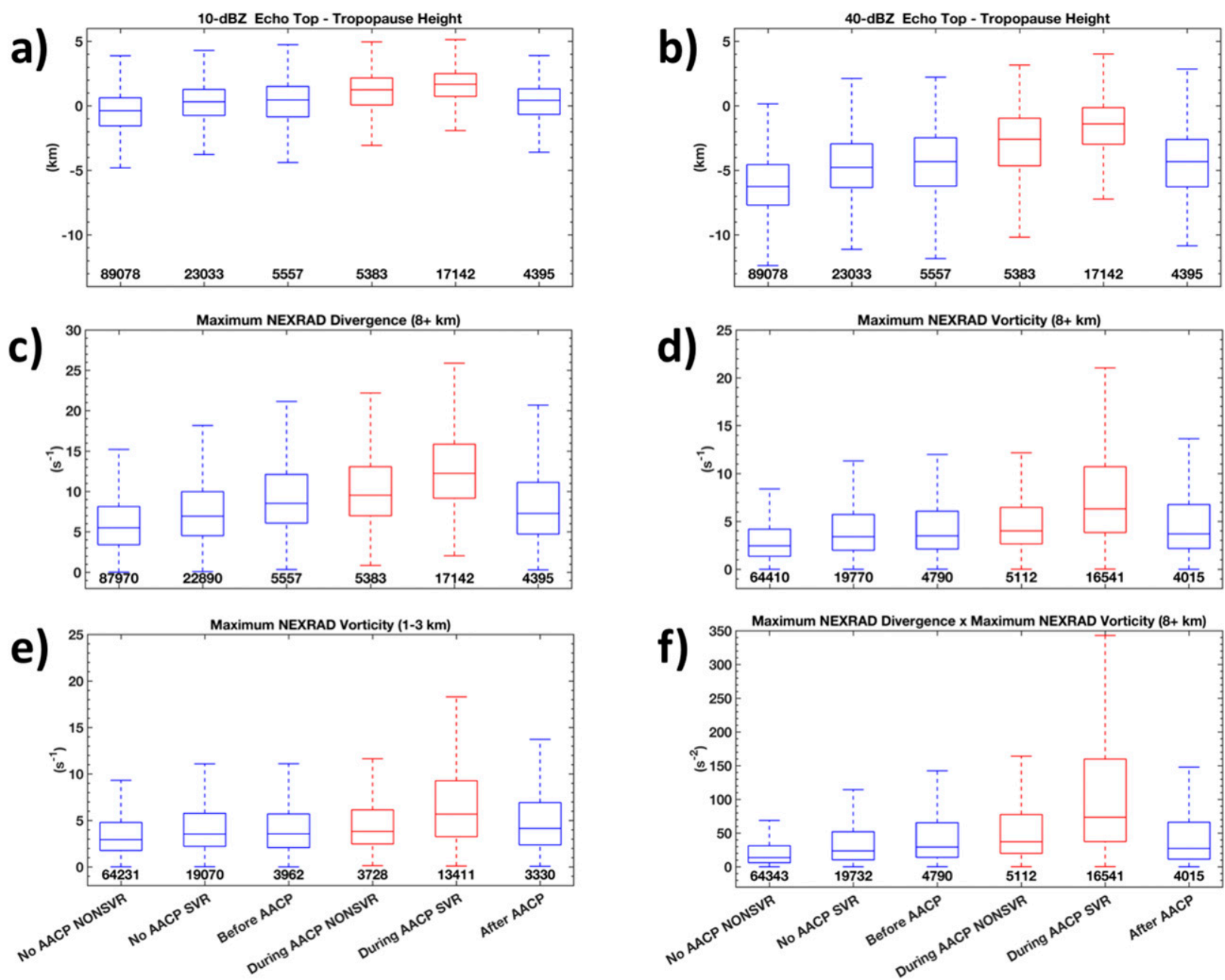

FIG. 7. Box-and-whisker diagrams showing the distributions of tropopause-relative (a) 10- and (b) 40-dBZ GridRad echo tops, (c) NEXRAD maximum storm cell divergence above an 8-km altitude, (d) maximum NEXRAD low-level (1-3 km) and (e) upper-level $(8+\mathrm{km})$ vorticity, and (f) the product of the maximum upper-level divergence and vorticity. The columns in each panel, from left to right, are 1) a non-AACP nonsevere storm, 2) a non-AACP severe storm, 3) the time period during a storm lifetime before an AACP appeared, 4) the time period during AACP production for a nonsevere storm, 5) the time period during AACP production for a severe storm, and 6) the time period during a storm lifetime after an AACP was no longer produced. The box shows the 25 th-75th percentiles of the data. The line within the box is the median of the distribution. The whiskers show the 2nd-98th percentiles.

and $40-\mathrm{dB} Z$ volumes in the mixed-phase region are highly correlated with lightning flash rate (Deierling and Petersen 2008; Liu et al. 2012).

GridRad indicators of updraft rotation at both low (1-3-km altitude; Fig. 7e) and upper levels (altitude of $8+\mathrm{km}$; Fig. $7 \mathrm{~d})$ show interesting distributions when analyzed across the six categories discussed above. Nonsevere, non-AACP storms have the weakest rotation and severe, non-AACP storms have an increasing tendency for greater rotation. Similar to the findings above, the time periods before and after an AACP look quite similar to those of a severe non-AACP storm. But contrary to the above, where echo-top height and divergence increased when an AACP formed regardless of storm severity, rotation does not increase during $\mathrm{AACP}$ production for nonsevere storms. Only severe AACP storms exhibit a significant rotation enhancement. The product of upperlevel rotation and divergence (Fig. 7f) is enhanced where intense, rotating updrafts are present and best distinguishes severe from nonsevere AACP storms, consistent with analyses of tornadic storms by Sandmæl et al. (2018).

The storm cell minimum GOES IR temperature is not significantly different across the six categories of storms (Fig. 8c). The coldest cloud tops are only $\sim 2 \mathrm{~K}$ colder when an AACP is being produced compared to nonAACP storms or before/after an AACP. This does provide further indication that updrafts are more intense when plumes are produced, but the small BT 

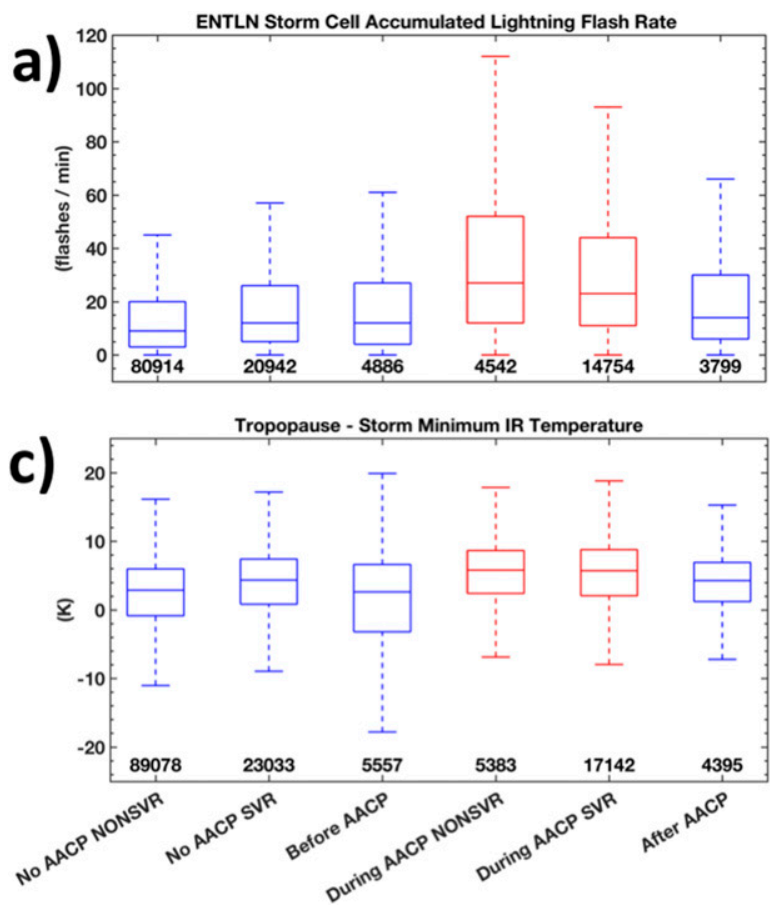

difference is inconsistent with larger updraft intensity differences inferred through $Z_{10-\mathrm{dB} Z}, Z_{40-\mathrm{dB} Z}$, and radial divergence. GOES visible texture magnitude, derived using the Bedka and Khlopenkov (2016) method within daytime storms, shows differences in inferred OT penetration through the anvil between AACP and nonAACP storms that are more consistent with the echotop-based metrics (Fig. 8b and Sandmæl et al. 2018). This demonstrates that many heavily precipitating storms can have cold cloud tops, but this information alone does not necessarily provide details about storm severity or the likelihood to generate an AACP. Therefore, algorithms that seek to discriminate a severe storm from a nonsevere storm based on IR temperature alone will often be ineffective. In a region with numerous storms of comparable IR BTs, one can differentiate the most intense storms via an AACP coupled with OT texture evident in visible imagery.

Intense, rotating updrafts are often present in supercells and, given that AACP storms feature these updrafts, it is not unreasonable to expect AACP storms to be supercells. It is found that $48 \%$ of AACP storms were supercells, based on the methods described in section 2a. This is not surprising given that AACP storm environments feature high CAPE and wind shear that is also favorable for supercells. Figure 9 demonstrates this similarity, but also that AACP storms and supercells occur in very similar environments to severe non-AACP storms. As expected, nonsevere, non-AACP storms occur in weaker CAPE and

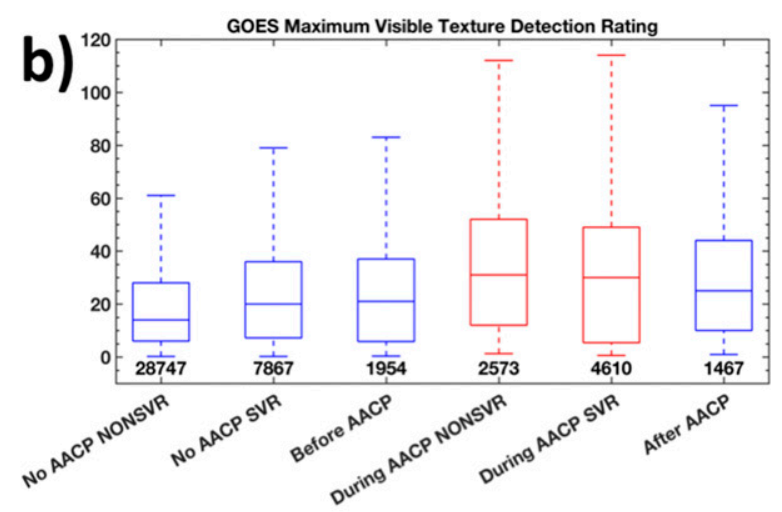

FIG. 8. As in Fig. 7, but featuring (a) ENTLN total lightning flash rate, (b) tropopause-relative storm minimum GOES IR BT, and (c) storm maximum GOES visible texture rating using the Bedka and Khlopenkov (2016) method.

shear environments (black line). Observations of storm updraft intensity through echo-top height, divergence, and rotation can better indicate a storm that is more likely to generate an AACP than environmental conditions. Of the 194 total supercells, 145 (75\%) produced an AACP. The $25 \%$ of supercells without an AACP had a mean $Z_{10-\mathrm{dB} Z}$ at the tropopause level, whereas the $75 \%$ of supercells with an AACP featured a mean $Z_{10-\mathrm{dB} Z} 1 \mathrm{~km}$ above the tropopause (not shown). Although there is some overlap in the two populations and some non-AACP supercells did penetrate the tropopause by $2 \mathrm{~km}$, the non-AACP supercells typically did not penetrate deeply enough into the stratosphere to generate a discernable AACP.

\section{c. Severe weather analysis}

It has been demonstrated that AACP storms are an especially intense subset of deep convection based on metrics discussed above. These findings and previous research strongly suggest they will be more severe on average than other storms. From a qualitative perspective, Fig. 6 shows there is often a clustering of severe weather reports along AACP tracks, especially during the 11 May 2014 and 16 May 2017 events. The AACP tracks are normally longer than those of non-AACP storms, typical of supercells. The 5 April 2017 case is the most anomalous of the four in that there are many extremely long-lived AACP storms in the southeast United States that were associated with very few or no reports. This area was within a NOAA/SPC zone of 

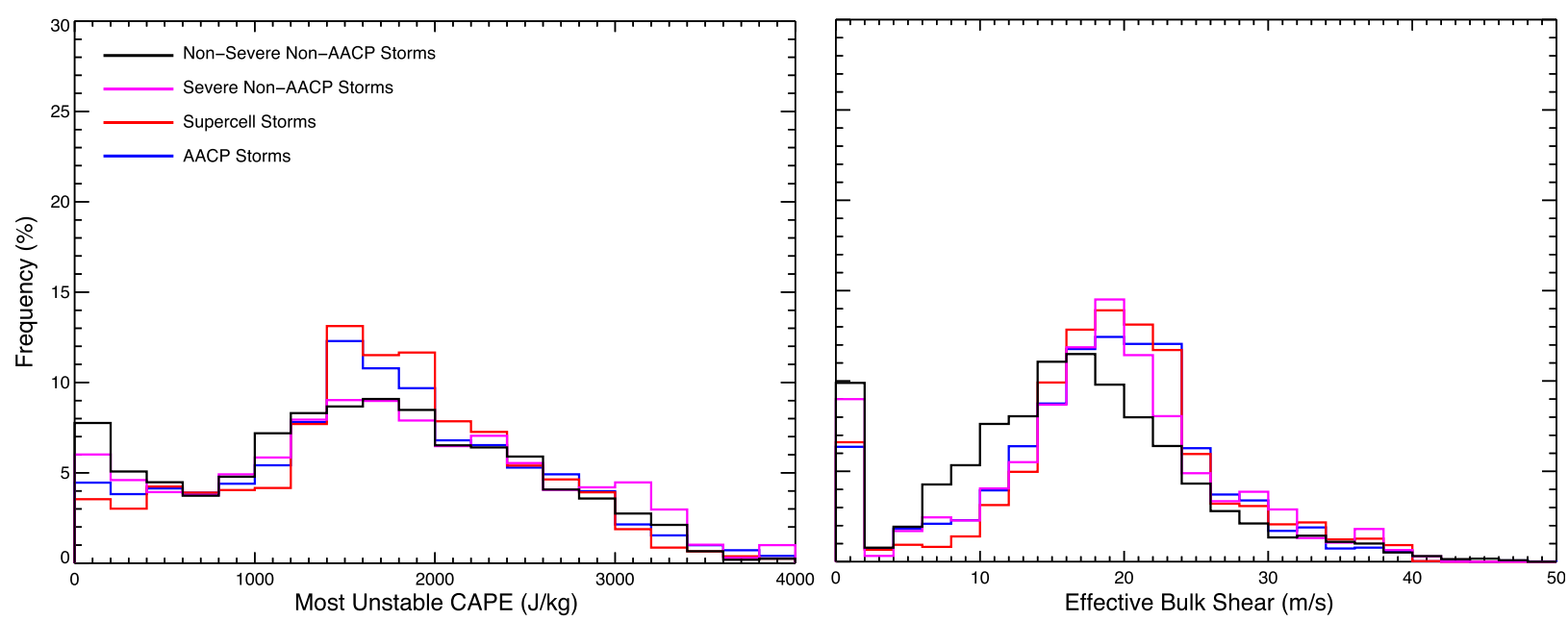

FIG. 9. Distributions of (left) most unstable CAPE and (right) 0-6-km effective bulk shear for AACP storms (blue), supercells (red), severe non-AACP storms (magenta), and nonsevere, non-AACP storms (black).

moderate risk for severe weather. Georgia and South Carolina were within a high risk area, which is used to define regions with thermodynamic and wind shear conditions extremely favorable for severe weather. While many long-tracked storms with intense updrafts occurred across this region, confirming the SPC risk assessment, it was peculiar that there were so few reports from these storms in such a favorable environment. There were several hail and wind reports from non-AACP storms across Alabama, Tennessee, and Kentucky on this day, exemplifying that AACPs cannot be used to detect all severe weather.

Severe weather relationships for the AACP and nonAACP storm populations are summarized in Table 2 . Among the AACP storms, 59\% generated some form of severe weather. Hail (tornado) was most (least) likely to be produced by an AACP storm. The overall low frequency of tornadoes explains this relationship, because, in general, only a small population of storms with evidence of strong rotating updrafts from Doppler radar produce a tornado. The relatively small fraction of AACP storms compared to the total (405 out of 4583 storms) generated $57 \%$ of all severe weather reports. If normalized by the number of storms in each category, AACP storms were responsible for 14 times the number of severe weather reports compared to non-AACP storms (6.33 vs 0.46 reports per storm). Of course, the existence of a trackable $40-\mathrm{dB} Z$ echo alone would not be a sufficient indicator of a severe storm, and inclusion of a large population of nonsevere storms decreases the number of reports per storm in this normalization. When all nonsevere storms are disregarded, AACP storms generated 2.6 times the number of reports per storm than nonAACP storms (10.8 vs 4.2 reports per severe storm).
Storms that produce significant severe weather are of greatest threat to public safety and property, and $\sim 73 \%$ of these reports are attributed to AACP storms in this study. Significant hail (88\%) and tornadoes $(86 \%)$ were most often associated with AACP storms, consistent with previous knowledge that supercells often generate AACPs and these hazards (see Duda and Gallus 2010 and references therein). The relationship between AACPs and significant severe wind is much lower (41\%), which may be attributed to the fact that 1) MCSs are often responsible for the majority of significant wind reports, 2) AACPs were found to be shorter lived in MCSs than in discrete cells, and 3) the short AACP lifetime and short-lived nature of GridRad cells within MCSs inhibited similar quality of evaluation between AACPs and severe weather. GOES-16 imagery from four randomly selected MCS events (Fig. 10) demonstrates that AACPs were present at the time of severe wind reports, many of which exceeded $33.4 \mathrm{~m} \mathrm{~s}^{-1}\left(\sim 75 \mathrm{mi} \mathrm{h}^{-1}\right)$. This suggests that AACPs may be more common in MCSs than our statistics suggest and AACPs could help recognize the most intense regions embedded within organized convective lines/ systems. Trapp et al. (2006) and Edwards et al. (2018) found that severe wind reports can be biased and/or misleading, which could also contribute to the reduced AACP-significant severe wind relationship.

AACPs typically appear in advance of severe weather reports, suggesting that the presence of a plume could be used by forecasters to aid in issuing severe weather warnings. Figure 11 (left panel) shows the distribution of the time difference between an initial AACP appearance and the first severe weather report from a storm, referred to here as lead time and based on an assumption 
TABLE 2. Severe weather characteristics of AACP storms, differentiated by severe weather type. Note that the fraction of AACP storms that produced hail, wind, or a tornado (column 2) should not average out to the fraction for any combination of severe weather.

\begin{tabular}{lccc}
\hline \hline & $\begin{array}{c}\text { Fraction of AACP storms } \\
\text { that produced the severe } \\
\text { weather hazard }(\%)\end{array}$ & $\begin{array}{c}\text { Fraction of severe reports } \\
\text { attributed to AACP storms (\%) }\end{array}$ & $\begin{array}{c}\text { Fraction of significant (SIG) } \\
\text { severe reports attributed to } \\
\text { AACP storms (\%) }\end{array}$ \\
\hline $\begin{array}{l}\text { Any combination of severe weather } \\
\left(N=4503, N_{\text {SIG }}=807\right)\end{array}$ & 59 & 57 & 73 \\
Hail $\left(N=3201, N_{\text {SIG }}=522\right)$ & 48 & 63 & 88 \\
Tornado $\left(N=272, N_{\text {SIG }}=28\right)$ & 16 & 68 & 86 \\
Wind $\left(N=1030, N_{\text {SIG }}=257\right)$ & 22 & 36 & 41 \\
\hline
\end{tabular}

of a maximum (minimum) lead time of $120(-30)$ minutes. The 120-min lead time was chosen because this was near the maximum provided by an AACP. A -30-min minimum lead time was chosen to account for situations when an NWS warning is issued after the first severe weather report is received. A total of 204 AACP storms that generated severe weather within this 150 -min time window also had an NWS warning. Nearly $85 \%$ of AACPs appeared before severe weather was reported, with a mean lead time of $31 \mathrm{~min}$. This lead-time distribution looks quite similar to that derived by McCann (1983, his Fig. 6) using GOES-3 imagery. Of the severe weather reports, $78 \%$ occurred while an AACP was actively being produced, with the remaining $22 \%$ being split nearly evenly between time periods before or after AACP production (not shown). These results are consistent with Fig. 7, which demonstrated that updrafts were strongest within AACP-producing storms and during the time AACPs were produced, favoring development of large hail and tornadoes.

It is also clear from Fig. 11 that the first severe thunderstorm or tornado warnings for AACP storms were issued by the NOAA NWS/well in advance of the first severe weather reports. It is important to note that although the first warning was issued well in advance of severe weather, this analysis is not focused on subsequent warnings (if any were issued) later in the storm lifetime. The fact that the first warning was issued with relatively long lead time is not especially surprising given that radar-derived storm characteristics prior to AACP production look quite similar to severe non-AACP storms, and these characteristics become more indicative of impending severe weather once the updraft intensifies, lightning flash rate increases, and an AACP is produced. The lead-time distributions for AACPs and NWS warnings are quite similar with the AACP (NWS) providing a 31- (34) min mean lead time and a 26-min standard deviation. Figure 11 (right panel, black line) shows that the AACP can provide $0-10$ min of additional lead time, but in general the first NWS warning is often issued $0-20 \mathrm{~min}$ before an AACP appearance, as AACPs preceded the NWS warning in $25 \%$ of the distribution (51 storms). Lead-time differences are also expressed in terms of percentage increase (blue line), defined as

$$
\text { percent increase }=\frac{100 \times(\text { NWS lead time }- \text { AACP lead time })}{\max (\text { NWS lead time }, \text { AACP lead time })} .
$$

This statistic accounts for the fact that, for example, 10 additional minutes of lead time provided by an AACP when severe weather occurs 90 min later may not be as meaningful as 10 additional minutes for a more imminent severe weather event. AACPs most often provide only a $0 \%-10 \%$ increase with a small opportunity for a greater increase. The NWS lead times are typically much greater on a percentage basis. Although it is clear the NWS forecasters are often identifying severe weather indicators using NEXRAD and other datasets prior to evidence of an AACP, the fact that the AACP alone can provide comparable warning lead time to an expert forecaster is a significant finding. This suggests AACPs can improve situational awareness and, as a result of this awareness, increase warning lead time.

Given that $88 \%$ of significant hail $(5+\mathrm{cm})$ reports were attributed to AACP storms, and severe weather most often occurs while an AACP is actively generated, knowledge that an AACP is being generated could increase NWS forecaster confidence that a given cell will produce significant hail. During the 13 severe weather events studied here, there were 2211 severe thunderstorm or tornado warnings issued by the NWS within the domains observed by GOES super rapid scanning, 1846 of which featured a "tag" indicating the maximum expected size of hail if hail is expected to occur. In total, 2338 storms were tagged to produce significant hail 


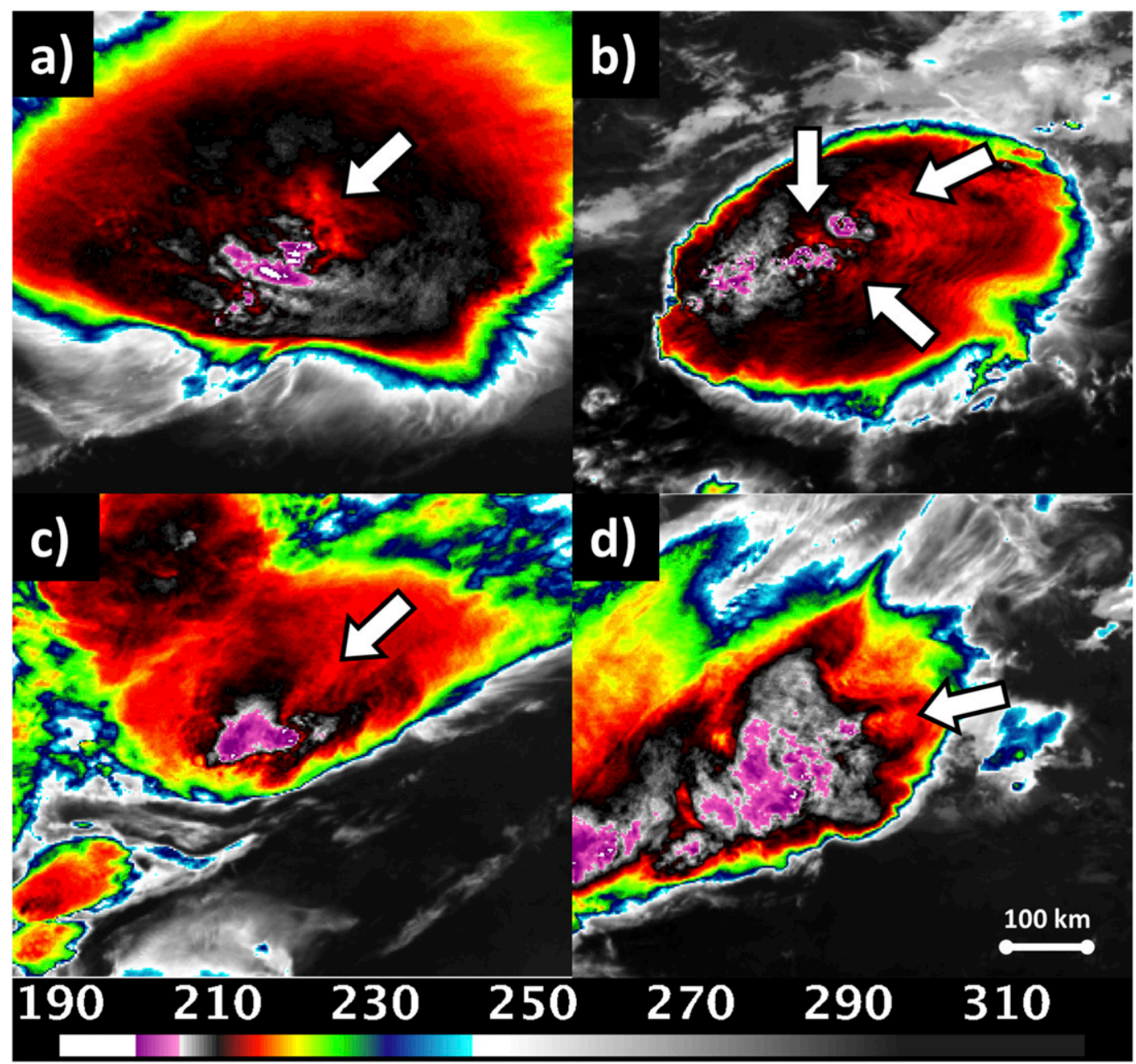

FIG. 10. GOES-16 IR imagery of randomly selected mesoscale convective systems at the time when severe winds were reported. Images are centered on the location where severe wind was reported. AACPs embedded within the MCS anvils are identified with white arrows: (a) 1302 UTC 11 Jun 2017 over Minnesota with $36 \mathrm{~m} \mathrm{~s}^{-1}\left(80.6 \mathrm{mi} \mathrm{h}^{-1}\right.$ ) wind, (b) 0032 UTC 17 Jun 2017 over Nebraska and Iowa with up to $49.4 \mathrm{~m} \mathrm{~s}^{-1}\left(110.5 \mathrm{mi} \mathrm{h}^{-1}\right)$ wind, (c) 0242 UTC 3 Jul 2017 over Nebraska with $33.4 \mathrm{~m} \mathrm{~s}^{-1}\left(74.8 \mathrm{mi} \mathrm{h}^{-1}\right)$ wind, and (d) 0302 UTC 4 Jul 2017 over Oklahoma with $31.4 \mathrm{~m} \mathrm{~s}^{-1}\left(70.2 \mathrm{mi} \mathrm{h}^{-1}\right)$ wind.

(127 storms had at least more than one storm within the warning polygon). For example, severe thunderstorm warning text for the storm shown in Fig. $4 \mathrm{i}$ is provided by Iowa State University (2018b), which stated that hail up to $4.4 \mathrm{~cm}\left(1.75 \mathrm{in}\right.$.) and $26.8 \mathrm{~m} \mathrm{~s}^{-1}\left(60 \mathrm{mi} \mathrm{h}^{-1}\right)$ winds were expected. The number of significant hail events included in this analysis increased from 522 (see section $2 \mathrm{~h}$ and Table 1) to 765 because we removed the requirement that GOES imagery must be available for the entire GridRad storm cell lifetime. We determine what fraction of NWS warnings with hail tags of $5+\mathrm{cm}$ were associated with significant severe hail, which defines the probability of detection (POD). Conversely, we determined the fraction of warnings for which significant hail was forecast but no significant hail was reported, which defines the false alarm ratio (FAR).
The POD and FAR are derived for a combined set of warnings: 1$)$ those with a hail tag of $5+\mathrm{cm}(2+\mathrm{in}$.) and 2) those warnings with a hail tag of $5+\mathrm{cm}$ or with an AACP. If an AACP was actively generated during a warning, we assume for this analysis that hail of $5+\mathrm{cm}$ was predicted. POD and FAR statistics and the sample sizes (parameters $A-C$ ) used to compute these statistics are provided in Table 3.

The results show that $13.9 \%$ of significant hail events were captured by NWS warnings with hail tags of $5+\mathrm{cm}$ but $75.3 \%$ of these tagged warnings were false alarms, namely that hail of $5+\mathrm{cm}$ never occurred despite being tagged. Warnings during AACP generation or with a hail tag of $5+\mathrm{cm}$ captured $98.5 \%$ of these reports. FAR increases by $\sim 11 \%$ when AACPs are included. The critical success index (CSI) increases by 

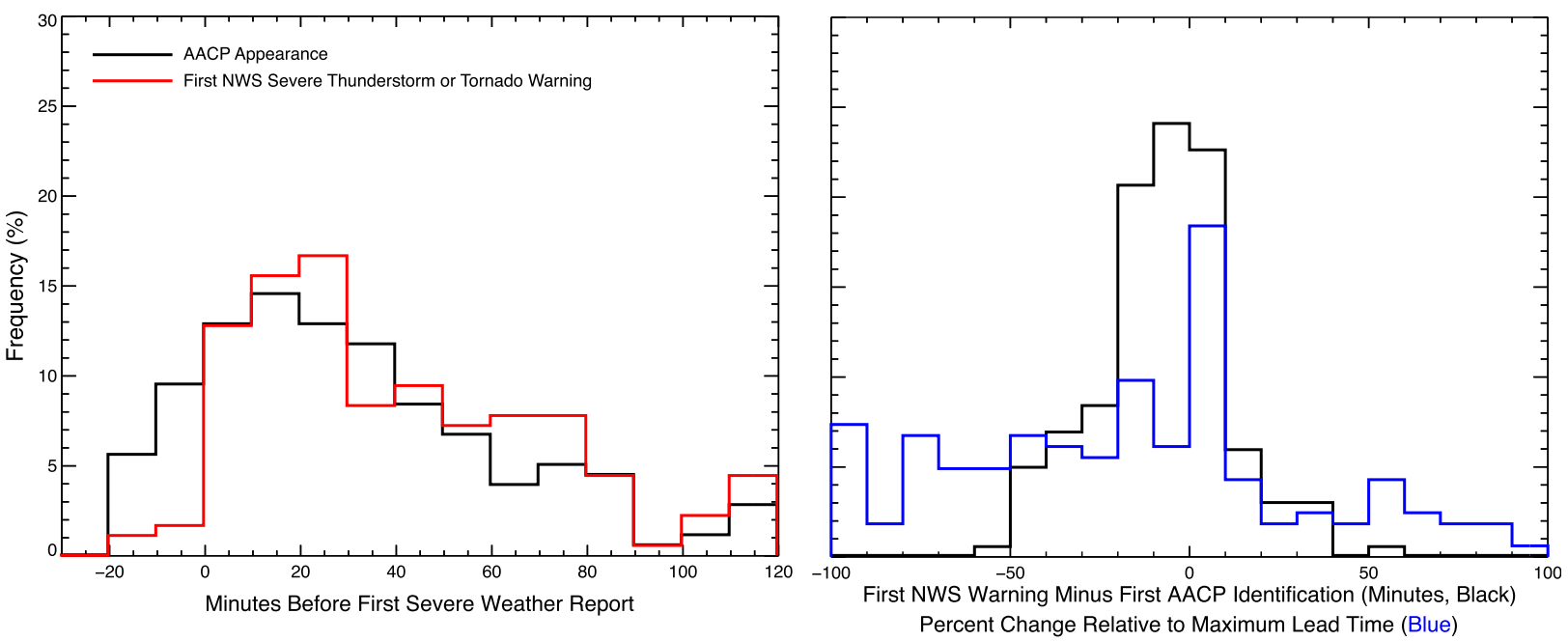

FIG. 11. (left) The distribution of time difference $(\mathrm{min})$ between when an AACP first appeared and the first severe weather was reported (black), and the time difference between the first NWS severe thunderstorm or tornado warning and first severe weather report (red). Positive values indicate that AACP or warning appeared before severe weather based on 236 storms that had an AACP, warning, and severe weather report. (right) The time difference between the AACP appearance and NWS's warning (black), with positive values indicating that the AACP appeared first ( $25 \%$ of the population). Shown is the difference between the AACP and warning time, expressed as a percentage relative to maximum lead time (blue) with positive values indicating that the AACP appeared before the first warning was issued.

0.04 because the substantial POD increase outweighs the relatively small FAR increase.

It is important to note that unreported large hail events or inaccurate hail size reports will bias the statistics, but these biases are inherent to all severe weather studies dependent on reports. It is likely that significant hail occurs more frequently than the reports suggest, which would lower the FAR statistics, but there is no way to know this for sure. FAR could also be lowered if, soon after forecaster identified an AACP, they were to look at radar and environmental information to see if significant hail was a realistic possibility before inserting a tag of $5+\mathrm{cm}$. Future work should include comparisons of NWS warnings and AACP with radar-derived hail size estimates, which are also imperfect but offer a more spatially continuous indication of hail swath unbiased by population density. Nevertheless, based on the sample of storms analyzed here, the large increase in POD indicates that forecasters' recognition of an AACP at the time of a warning could improve their confidence that significant hail will occur and encourage them to increase their hail size tag.

\section{Summary}

Although the AACP has been recognized in satellite imagery for over 35 years and has been qualitatively linked to the occurrence of severe weather in numerous studies, few studies to date have 1) analyzed AACP storm dynamics using ground-based radar and lightning observations, 2) compared AACP storm characteristics with non-AACP severe storms, and 3) quantified AACP-severe weather relationships and lead time relative to NWS warnings. The results of this study demonstrate that, on average, storms that produce an AACP are an especially intense subset of deep convection, featuring the highest cloud tops, strongest updrafts, most lightning, a high frequency of severe weather, and characteristics of a supercell storm in about half the cases. The first indicators of an AACP precede severe weather by over $30 \mathrm{~min}$ on average, and preceded NWS warnings in $25 \%$ of severe AACP storms. Generation of an AACP during an NWS warning showed a large increase in the likelihood that significant hail would occur.

In the warning process, forecasters are often considering multiple, complex datasets that provide near-real-time inferences of in-storm dynamical and microphysical processes linked to severe weather. The NOAA NEXRAD radar network has gaps and deficiencies, so the existence of an AACP in underobserved regions can be used over the United States and globally as a key decision aid for severe weather warning. AACPs can be identified in GEOsat or low-Earth-orbiting satellite imagery by anyone after a limited amount of training, enabling a forecaster to quickly recognize these significant severe storms. This is especially true when 1-min or better super rapid scan imagery is available, which allows one to best see the, sometimes, subtle indicators of an AACP and maximize lead time. The presence of an AACP 
TABLE 3. POD, FAR, and CSI for storms with NWS warnings with a 5-cm (2+ in.) hail tag and any warning coincident with AACP generation based on an analysis of 2211 NWS severe thunderstorm or tornado warnings across 13 severe weather events.

\begin{tabular}{lcc}
\hline \hline & $\begin{array}{c}\text { NWS warnings with } \\
\text { 5-cm }(2+\text { in. }) \text { tag }\end{array}$ & $\begin{array}{c}\text { NWS warnings with 5-cm (2+ in.) } \\
\text { tag or AACP classification }\end{array}$ \\
\hline POD $(A / A+C)$ & 0.139 & 0.985 \\
FAR $(B / A+B)$ & 0.753 & 0.864 \\
CSI $(A / A+B+C)$ & 0.098 & 0.136 \\
No. of warnings that were hits $(A)$ & 37 & 262 \\
No. of warnings that were false alarms $(B)$ & 113 & 1658 \\
No. of warnings with $<5$-cm tag or without & 229 & 4 \\
an AACP coincident with hail of $5+\mathrm{cm}(C)$ & & \\
\hline
\end{tabular}

could improve forecaster confidence to issue a warning in situations where radar signals are ambiguous or radar data are of reduced quality or unavailable. In addition, AACPs can be used to quickly identify the most intense storms, providing valuable situational awareness. Monitoring AACP characteristics can help a forecaster identify updraft intensification or decay that may not be depicted well in a single volume of NEXRAD data available in routine NOAA/NWS forecast operations. Knowledge that an updraft has recently intensified, especially when identified in super rapid scan imagery, can influence a forecaster decision to issue a warning and possibly extend warning lead time. Given that AACPs have been documented throughout the world, and the majority are not observed by Doppler radar, the AACP-based severe storm identification capability could help save lives and protect property. Although the ENTLN analysis in this paper indicates that lightning flash rate increases sharply as updrafts intensify and AACPs are produced, future work should be devoted to understanding how the first evidence of an AACP compares with output from lightning jump detection algorithms based on GOES-R series Geostationary Lightning Mapper data, which will be analyzed in the warning process for many years to come.

The cases featured in this paper were located primarily across the Midwest and Southeast United States during the spring and summer, so there is some uncertainty as to how often AACPs occur in other regions/seasons across the United States and the severity of these storms compared to the results described above. Supercell storms and extremely prominent overshooting updrafts (Cooney et al. 2018) are most common in the Midwest and Southeast, so we would expect AACPs to be most frequent in these regions. However, storms with AACPs certainly occur elsewhere and during other times of year according to Brunner et al. (2007). Future work should be devoted to analyzing significant severe weather occurrences in other regions/seasons to determine how often AACPs are associated with these events.
Lingering areas of uncertainty lie with the interpretation of AACP IR temperature and microphysics. This temperature and/or microphysical ambiguity, especially when evident within neighboring storms (Fig. 1), will challenge a forecaster's ability to understand and identify AACPs. Convection-permitting models could be used to address this uncertainty, such as those described by Wang et al. (2016) and Homeyer et al. (2017) and references therein, provided they can generate realistic simulations of multiple AACPs with disparate temperature and microphysics in relatively close proximity to each other. Another avenue of research would be to pair space- (i.e., CALIOP; Setvák et al. 2013) or airborne lidar observations of AACPs with satellite IR and nearby temperature profiles from rawinsonde or reanalysis to understand the vertical distribution of clouds and their ambient temperature environment. Radar volumes such as those from GridRad would be required to capture the storm temporal evolution to determine how inferred OT region height and updraft intensity relate to AACP height, temperature, and reflectance.

Although human analysts can identify AACPs with high accuracy, an automated AACP detection algorithm is required to determine the global distribution of AACP storms, extend AACP-severe weather analyses beyond a limited number of days, and analyze and quantify the impact of AACPs on stratospheric composition. Firstgeneration AACP detection methods developed within the GOES-R Algorithm Working Group (Bedka et al. 2011) and in Europe (Iršič Žibert and Žibert 2013) demonstrated that automated detection is possible, but there is opportunity to improve upon these methods using advanced pattern recognition approaches.

Acknowledgments. This work was supported by the NASA Severe Weather Research Program under Award NNX15AV81G. The authors thank the University of Wisconsin Space Science and Engineering Center Data Center for providing GOES satellite data analyzed in this 
study and for McIDAS software support. We thank Thea Sandmæl for her assistance with assembling the storm track datasets and other insights that helped improve this paper, and James Correia Jr. for providing supplemental material for warning analyses. We thank Jason Apke, Kim Runk, Phil Schumacher, and Chauncy Schultz for their comments and suggestions that helped to improve the paper. We also thank Martin Setvák and Pao Wang for their insight over the years and for their efforts to better understand AACPs and communicate this information to the forecasting and research communities.

\section{REFERENCES}

Achtor, T., T. Rink, R. Whittaker, D. Parker, and D. Santek, 2008 McIDAS-V: A Powerful data analysis and visualization tool for multi and hyperspectral environmental satellite data. Proc. SPIE, 7085, 708509, https://doi.org/10.1117/12.795223.

Adler, R. F., M. J. Markus, D. D. Fenn, G. Szejwach, and W. E. Shenk, 1983: Thunderstorm top structure observed by aircraft overflights with an infrared radiometer. J. Climate Appl. Meteor., 22, 579-593, https://doi.org/10.1175/1520-0450(1983) $022<0579$ :TTSOBA $>2.0 . \mathrm{CO} ; 2$.

Anderson, J. G., and Coauthors, 2017: Stratospheric ozone over United States in summer linked to observations of convection and temperature via chlorine and bromine catalysis. Proc. Natl. Acad. Sci. USA, 114, E4905-E4913, https://doi.org/ 10.1073/pnas.1619318114.

Apke, J. M., J. R. Mecikalski, and C. P. Jewett, 2016: Analysis of mesoscale atmospheric flows above mature deep convection using super rapid scan geostationary satellite data. J. Appl. Meteor. Climatol., 55, 1859-1887, https://doi.org/10.1175/ JAMC-D-15-0253.1.

, K. M. Bedka, E. W. McCaul, C. R. Homeyer, and C. P. Jewett, 2018: Relationships between deep convection updraft characteristics and satellite based Super Rapid Scan mesoscale atmospheric motion vector derived flow. Mon. Wea. Rev., https://doi.org/10.1175/MWR-D-18-0119.1, in press.

Bedka, K. M., and K. Khlopenkov, 2016: A probabilistic pattern recognition method for detection of overshooting cloud tops using satellite imager data. J. Appl. Meteor. Climatol., 55, 1983-2005, https://doi.org/10.1175/JAMC-D-15-0249.1.

_ J. Brunner, R. Dworak, W. Feltz, J. Otkin, and T. Greenwald, 2010: Objective satellite-based overshooting top detection using infrared window channel brightness temperature gradients. J. Appl. Meteor. Climatol., 49, 181-202, https://doi.org/ 10.1175/2009JAMC2286.1.

- - _ , and W. Feltz, 2011: Overshooting top and enhanced-V signature detection for the GOES-R Advanced Baseline Imager. Algorithm Theoretical Basis Document, NOAA/NESDIS/Center for Satellite Applications and Research, 75 pp., http://clouds.larc. nasa.gov/site/people/data/kbedka/GOES-R_ABI_ATBD_ OvershootingTop_Enhanced-V_100perc.doc.

—, C. Wang, R. Rogers, L. Carey, W. Feltz, and J. Kanak, 2015: Examining deep convective cloud evolution using total lightning, WSR-88D, and GOES-14 Super Rapid Scan datasets. Wea. Forecasting, 30, 571-590, https://doi.org/10.1175/WAFD-14-00062.1.

Brotzge, J., S. Erickson, and H. Brooks, 2011: A 5-yr climatology of tornado false alarms. Wea. Forecasting, 26, 534-544, https:// doi.org/10.1175/WAF-D-10-05004.1.
Browning, K. A., and R. J. Donaldson, 1963: Airflow and structure of a tornadic storm. J. Atmos. Sci., 20, 533-545, https://doi.org/ 10.1175/1520-0469(1963)020<0533:AASOAT>2.0.CO;2.

Brunner, J. C., S. A. Ackerman, A. S. Bachmeier, and R. M. Rabin, 2007: A quantitative analysis of the enhanced-V feature in relation to severe weather. Wea. Forecasting, 22, 853-872, https://doi.org/10.1175/WAF1022.1.

Cappucci, M., 2018: Giant hail pummeled an Argentine city Thursday, possibly a Southern Hemisphere record. Washington Post, 9 February, https://www.washingtonpost.com/ news/capital-weather-gang/wp/2018/02/09/hail-largerthan-softballs-pummeled-an-argentina-city-on-thursday/ ?utm_term $=$.ed22ac0a62e8.

Cintineo, J. L., M. J. Pavolonis, J. M. Sieglaff, and A. K. Heidinger, 2013: Evolution of severe and nonsevere convection inferred from GOES-derived cloud properties. J. Appl. Meteor. Climatol., 52, 2009-2023, https://doi.org/ 10.1175/JAMC-D-12-0330.1.

Cooney, J. W., K. P. Bowman, C. R. Homeyer, and T. M. Fenske, 2018: Ten year analysis of tropopause-overshooting convection using GridRad data. J. Geophys. Res. Atmos., 123, 329343, https://doi.org/10.1002/2017JD027718.

Deierling, W., and W. A. Petersen, 2008: Total lightning activity as an indicator of updraft characteristics. J. Geophys. Res., 113, D16210, https://doi.org/10.1029/2007JD009598.

Doswell, C. A., III, and D. W. Burgess, 1993: Tornadoes and tornadic storms: A review of conceptual models. The Tornado: Its Structure, Dynamics, Prediction, and Hazards, Geophys. Monogr., Vol. 79, Amer. Geophys., Union, 161-172, https:// dx.doi.org/10.1029/GM079p0161.

- H. E. Brooks, and M. P. Kay, 2005: Climatological estimates of daily local nontornadic severe thunderstorm probability for the United States. Wea. Forecasting, 20, 577-595, https://doi. org/10.1175/WAF866.1.

Duda, J. D., and W. A. Gallus Jr., 2010: Spring and summer midwestern severe weather reports in supercells compared to other morphologies. Wea. Forecasting, 25, 190-206, https://doi.org/ 10.1175/2009WAF2222338.1.

Dworak, R., K. M. Bedka, J. Brunner, and W. Feltz, 2012: Comparison between GOES-12 overshooting top detections, WSR-88D radar reflectivity, and severe storm reports. Wea. Forecasting, 27, 684-699, https://doi.org/ 10.1175/WAF-D-11-00070.1.

Edwards, R., J. T. Allen, and G. W. Carbin, 2018: Reliability and climatological impacts of convective wind estimations. J. Appl. Meteor. Climatol., 57, 1825-1845, https://doi.org/10.1175/ JAMC-D-17-0306.1.

EUMETSAT, 2018: Best practices for RGB compositing of multispectral imagery. User Service Division, EUMETSAT, 8 pp., http://oiswww.eumetsat.int/ idds/html/doc/best_practices.pdf.

Fujita, T., 1958: Mesoanalysis of the Illinois tornadoes of 9 April 1953. J. Meteor., 15, 288-296, https://doi.org/10.1175/15200469(1958)015<0288:MOTITO>2.0.CO;2.

- 1974: Overshooting thunderheads observed from ATS and Learjet. Satellite and Mesometeorology Research Project Rep. 117, Texas Tech University, Lubbock, TX, 29 pp.

_ 1982: Principle of stereographic height computations and their application to stratospheric cirrus over severe thunderstorms. J. Meteor. Soc. Japan, 60, 355-368, https://doi.org/ 10.2151/jmsj1965.60.1_355.

Goodman, S. J., and Coauthors, 2013: The GOES-R Geostationary Lightning Mapper (GLM). Atmos. Res., 125-126, 34-49, https://doi.org/10.1016/j.atmosres.2013.01.006. 
Hales, J. E., Jr., 1988: Improving the watch/warning program through use of significant event data. Preprints, 15th Conf. on Severe Local Storms, Baltimore, MD, Amer. Meteor. Soc., 165-168.

Heymsfield, G. M., R. H. Blackmer, and S. Schotz, 1983: Upper-level structure of Oklahoma tornadic storms on 2 May 1979. I: Radar and satellite observations. J. Atmos. Sci., 40, 1740-1755, https:// doi.org/10.1175/1520-0469(1983)040<1740:ULSOOT $>2.0 . C O ; 2$.

Homeyer, C. R., 2014: Formation of the enhanced-V infrared cloud-top feature from high-resolution three-dimensional radar observations. J. Atmos. Sci., 71, 332-348, https://doi.org/ 10.1175/JAS-D-13-079.1.

_—, and K. P. Bowman, 2017: Algorithm description document for version 3.1 of the three-dimensional gridded NEXRAD WSR-88D radar (GridRad) dataset. University of OklahomaTexas A\&M University, 23 pp., http://gridrad.org/pdf/GridRadv3.1-Algorithm-Description.pdf.

,-- , and L. L. Pan, 2010: Extratropical tropopause transition layer characteristics from high-resolution sounding data. J. Geophys. Res., 115, D13108, https://doi.org/10.1029/ 2009JD013664.

_ J. D. McAuliffe, and K. M. Bedka, 2017: On the development of above-anvil cirrus plumes in extratropical convection. J. Atmos. Sci., 74, 1617-1633, https://doi.org/10.1175/JAS-D16-0269.1.

Iowa State University, 2018a: Archived NWS watch/warnings. Iowa Environmental Mesonet, Iowa State University, https:// mesonet.agron.iastate.edu/request/gis/watchwarn.phtml.

, 2018b: 2017 [KSJT] SAN_ANGELO severe thunderstorm (SV) warning (W) number 77. Iowa Environmental Mesonet, Iowa State University, https://mesonet.agron.iastate.edu/vtec/\#2017-ONEW-KSJT-SV-W-0077/USCOMP-NOQ-201705190000.

Iršič Žibert, M., and J. Žibert, 2013: Monitoring and automatic detection of the cold-ring patterns atop deep convective clouds using Meteosat data. Atmos. Res., 123, 281-292, https:// doi.org/10.1016/j.atmosres.2012.08.007.

Koch, S. E., R. Ware, H. Jiang, and Y. Xie, 2016: Rapid mesoscale environmental changes accompanying genesis of an unusual tornado. Wea. Forecasting, 31, 763-786, https://doi.org/ 10.1175/WAF-D-15-0105.1.

Kumjian, M. R., and A. V. Ryzhkov, 2008: Polarimetric signatures in supercell thunderstorms. J. Appl. Meteor. Climatol., 47, 1940-1961, https://doi.org/10.1175/2007JAMC1874.1.

Kunz, M., U. Blahak, J. Handwerker, M. Schmidberger, H. J. Punge, S. Mohr, E. Fluck, and K. M. Bedka, 2018: The severe hailstorm in southwest Germany on 28 July 2013: Characteristics, impacts and meteorological conditions. Quart. J. Roy. Meteor. Soc., 144, 231-250, https://doi.org/10.1002/qj.3197.

Lazzara, M. A., and Coauthors, 1999: The Man computer Interactive Data Access System: 25 years of interactive processing. Bull. Amer. Meteor. Soc., 80, 271-284, https://doi.org/ 10.1175/1520-0477(1999)080<0271:TMCIDA > 2.0.CO;2.

Lemon, L. R., and C. A. Doswell III, 1979: Severe thunderstorm evolution and mesocyclone structure as related to tornadogenesis. Mon. Wea. Rev., 107, 1184-1197, https://doi.org/ 10.1175/1520-0493(1979)107<1184:STEAMS>2.0.CO;2.

Lenz, A., K. M. Bedka, W. F. Feltz, and S. A. Ackerman, 2009: Convectively-induced transverse band signatures in satellite imagery. Wea. Forecasting, 24, 1362-1373, https://doi.org/ 10.1175/2009WAF2222285.1.

Levizzani, V., and M. Setvák, 1996: Multispectral, high-resolution satellite observations of plumes on top of convective storms. $J$. Atmos. Sci., 53, 361-369, https://doi.org/10.1175/1520-0469 (1996)053<0361:MHRSOO>2.0.CO;2.
Lindsey, D. T., and M. J. Bunkers, 2005: Observations of a severe, left-moving supercell on 4 May 2003. Wea. Forecasting, 20, 1522, https://doi.org/10.1175/WAF-830.1.

— , D. W. Hillger, L. Grasso, J. A. Knaff, and J. F. Dostalek, 2006: GOES climatology and analysis of thunderstorms with enhanced 3.9- $\mu \mathrm{m}$ reflectivity. Mon. Wea. Rev., 134, 2342-2353, https://doi.org/10.1175/MWR3211.1.

Line, W. E., T. J. Schmit, D. T. Lindsey, and S. J. Goodman, 2016: Use of geostationary super rapid scan satellite imagery by the Storm Prediction Center. Wea. Forecasting, 31, 483-494, https://doi.org/10.1175/WAF-D-15-0135.1.

Liu, C., and S. Heckman, 2010: The application of total lightning detection and cell tracking for severe weather prediction. Technical Conf. on Meteorology and Environmental Instruments and Methods of Observation, Helsinki, Finland, WMO, https://www. wmo.int/pages/prog/www/IMOP/publications/IOM-104_TECO2010/P2_7_Heckman_USA.pdf.

_, D. J. Cecil, E. J. Zipser, K. Kronfeld, and R. Robertson, 2012: Relationships between lightning flash rates and radar reflectivity vertical structures in thunderstorms over the tropics and subtropics. J. Geophys. Res., 117, D06212, https://doi.org/ 10.1029/2012JB009290.

McCann, D. W., 1983: The enhanced-V: A satellite observable severe storm signature. Mon. Wea. Rev., 111, 887-894, https://doi.org/ 10.1175/1520-0493(1983)111<0887:TEVASO > 2.0.CO; 2 .

Mesinger, F., and Coauthors, 2006: North American Regional Reanalysis. Bull. Amer. Meteor. Soc., 87, 343-360, https://doi.org/ 10.1175/BAMS-87-3-343.

Púčik, T., M. Valachová, and P. Zacharov, 2013: Upper tropospheric conditions in relation to the cloud top features of 15 August 2010 convective storms. Atmos. Res., 123, 249-267, https://doi.org/10.1016/j.atmosres.2012.10.006.

Rosenfeld, D., W. L. Woodley, A. Lerner, G. Kelman, and D. T. Lindsey, 2008: Satellite detection of severe convective storms by their retrieved vertical profiles of cloud particle effective radius and thermodynamic phase. J. Geophys. Res., 113, D04208, https://doi.org/10.1029/ 2007JD008600.

Sandmæl, T. N., 2017: An evaluation of radar- and satellite-data based products to discriminate between tornadic and non-tornadic storms. School of Meteorology, University of Oklahoma, 98 pp., https:/hdl.handle.net/11244/52775.

Schmit, T. J., M. M. Gunshor, W. P. Menzel, J. Li, S. Bachmeier, and J. J. Gurka, 2005: Introducing the next-generation Advanced Baseline Imager (ABI) on GOES-R. Bull. Amer. Meteor. Soc., 86, 1079-1096, https://doi.org/10.1175/BAMS86-8-1079.

—_ and Coauthors, 2014: GOES-14 Super Rapid Scan operations to prepare for GOES-R. J. Appl. Remote Sens., 7, 073462 , https://doi.org/10.1117/1.JRS.7.073462.

Schultz, C. J., W. A. Petersen, and L. D. Carey, 2009: Preliminary development and evaluation of lightning jump algorithms for the real-time detection of severe weather. J. Appl. Meteor. Climatol., 48, 2543-2563, https://doi.org/ 10.1175/2009JAMC2237.1.

$\longrightarrow,-$, and — 2011: Lightning and severe weather: A comparison between total and cloud-to-ground lightning trends. Wea. Forecasting, 26, 744-755, https://doi.org/10.1175/ WAF-D-10-05026.1.

Setvák, M., and C. A. Doswell III, 1991: The AVHRR channel 3 cloud top reflectivity of convective storms. Mon. Wea. Rev., 119, 841-847, https://doi.org/10.1175/1520-0493(1991)119<0841: TACCTR $>2.0 . C O ; 2$. 
_ and Coauthors, 2010: Satellite-observed cold-ring-shaped features atop deep convective clouds. Atmos. Res., 97, 80-96, https://doi.org/10.1016/j.atmosres.2010.03.009.

— , K. Bedka, D. T. Lindsey, A. Sokol, Z. Charvat, J. Stastka, and P. K. Wang, 2013: A-Train observations of deep convective storm tops. Atmos. Res., 123, 229-248, https://doi.org/10.1016/ j.atmosres.2012.06.020.

Smith, J. B., and Coauthors, 2017: A case study of convectively sourced water vapor observed in the overworld stratosphere over the United States. J. Geophys. Res. Atmos., 122, 95299554, https://doi.org/10.1002/2017JD026831.

Smith, R. B., 1980: Linear theory of stratified hydrostatic flow past an isolated mountain. Tellus, 32, 348-364, https://doi.org/ 10.3402/tellusa.v32i4.10590.

Smith, T. M., and Coauthors, 2016: Multi-Radar Multi-Sensor (MRMS) severe weather and aviation products: Initial operating capabilities. Bull. Amer. Meteor. Soc., 97, 1617-1630, https://doi.org/10.1175/BAMS-D-14-00173.1.

Solomon, D. L., K. P. Bowman, and C. R. Homeyer, 2016: Tropopause-penetrating convection from three-dimensional gridded NEXRAD data. J. Appl. Meteor. Climatol., 55, 465478, https://doi.org/10.1175/JAMC-D-15-0190.1.

Starzec, M., C. R. Homeyer, and G. L. Mullendore, 2017: Storm Labeling in Three Dimensions (SL3D): A volumetric radar echo and dual-polarization updraft classification algorithm. Mon. Wea. Rev., 145, 1127-1145, https://doi.org/10.1175/MWR-D-16-0089.1.

Thompson, R. L., C. M. Mead, and R. Edwards, 2007: Effective storm-relative helicity and bulk shear in supercell thunderstorm environments. Wea. Forecasting, 22, 102-115, https:// doi.org/10.1175/WAF969.1.
Trapp, R. J., G. J. Stumpf, and K. L. Manross, 2005: A reassessment of the percentage of tornadic mesocyclones. Wea. Forecasting, 20, 680-687, https://doi.org/10.1175/WAF864.1.

_ D. M. Wheatley, N. T. Atkins, R. W. Przybylinski, and R. Wolf, 2006: Buyer beware: Some words of caution on the use of severe wind reports in postevent assessment and research. Wea. Forecasting, 21, 408-415, https://doi.org/10.1175/WAF925.1.

University of Wyoming, 2018: 87344 SACO Cordero Aero. University of Wyoming, http://weather.uwyo.edu/cgi-bin/sounding? region $=$ samer $\&$ TYPE $=$ GIF $\% 3$ ASKEWT $\&$ YEAR $=2018 \&$ $\mathrm{MONTH}=02 \& \mathrm{FROM}=0812 \& \mathrm{TO}=0812 \& \mathrm{STNM}=87344$

Verbout, S. M., H. E. Brooks, L. M. Leslie, and D. M. Schultz, 2006: Evolution of the U.S. tornado database: 1954-2003. Wea. Forecasting, 21, 86-93, https://doi.org/10.1175/WAF910.1.

Wang, P. K., 2003: Moisture plumes above thunderstorm anvils and their contributions to cross tropopause transport of water vapor in midlatitudes. J. Geophys. Res., 108, 4194, https://doi.org/ 10.1029/2002JD002581.

—, K.-Y. Cheng, M. Setvák, and C.-K. Wang, 2016: The origin of the gullwing-shaped cirrus above an Argentinian thunderstorm as seen in CALIPSO images. J. Geophys. Res. Atmos., 121, 3729-3738, https://doi.org/10.1002/2015JD024111.

Witt, A., M. D. Eilts, G. J. Stumpf, J. T. Johnson, E. D. Mitchell, and K. W. Thomas, 1998: An enhanced hail detection algorithm for the WSR-88D. Wea. Forecasting, 13, 286-303, https://doi.org/10.1175/ 1520-0434(1998)013<0286:AEHDAF>2.0.CO;2.

Yost, C. R., and Coauthors, 2018: A prototype method for diagnosing high ice water content probability using satellite imager data. Atmos. Meas. Tech., 11, 1615-1637, https://doi.org/ 10.5194/amt-11-1615-2018. 